\title{
Risk factors and modes of failure in the modern dual mobility implant. A systematic review and meta-analysis
}

\author{
Fu-Yuan Pai ${ }^{1,2}$, Hsuan-Hsiao Ma ${ }^{1,2}$, Te-Feng Arthur Chou ${ }^{1,2}$, Tsan-Wen Huang ${ }^{3,4}$, Kuo-Chin Huang ${ }^{3,4}$,
} Shang-Wen Tsai ${ }^{1,2}$, Cheng-Fong Chen ${ }^{1,2^{*}}$ and Wei-Ming Chen ${ }^{1,2}$

\begin{abstract}
Background: The aims of this meta-analysis were to: (1) validate the outcome of modern dual mobility (DM) designs in patients who had undergone primary and revision total hip arthroplasty (THA) procedures and (2) to identify factors that affect the outcome.

Methods: We searched for studies that assessed the outcome of modern DM-THA in primary and revision procedures that were conducted between January, 2000 to August, 2020 on PubMed, MEDLINE, Cochrane Reviews and Embase. The pooled incidence of the most common failure modes and patient reported outcomes were evaluated in patients who have received: (1) primary THA, (2) revision THA for all causes or (3) for recurrent dislocation. A meta-regression analysis was performed for each parameter to determine the association with the outcome. The study design of each study was assessed for potential bias and flaws by using the quality assessment tool for case series studies.

Results: A total of 119 studies ( $N=30016$ DM-THAs) were included for analysis. The mean follow-up duration was 47.3 months. The overall implant failure rate was $4.2 \%$ (primary: $2.3 \%$, revision for all causes: $5.5 \%$, recurrent dislocation: 6.0\%). The most common failure modes were aseptic loosening (primary: $0.9 \%$, revision for all causes: 2.2\%, recurrent dislocation: $2.4 \%$ ), septic loosening (primary:0.8\%, revision for all causes: $2.3 \%$, recurrent dislocation: 2.5\%), extra-articular dislocation (primary:0.6\%, revision for all causes:1.3\%, recurrent dislocation:2.5\%), intra-prosthetic dislocation (primary:0.8\%, revision for all causes:1.0\%, recurrent dislocation:1.6\%) and periprosthetic fracture (primary: $0.9 \%$, revision for all causes:0.9\%, recurrent dislocation:1.3\%). The multi-regression analysis identified younger age ( $\beta=-0.04,95 \% \mathrm{Cl}-0.07--0.02)$ and female patients ( $\beta=3.34,95 \% \mathrm{Cl} 0.91-5.78)$ were correlated with higher implant failure rate. Age, gender, posterolateral approach and body mass index (BMI) were not risk factors for extra-articular or intra-prosthetic dislocation in this cohort. The overall Harris hip score and Merle d'Aubigné score were 84.87 and 16.36, respectively. Level of evidence of this meta-analysis was IV.
\end{abstract}

\footnotetext{
* Correspondence: cfchen.vghtpe@gmail.com

'Department of Orthopaedics and Traumatology, Taipei Veterans General Hospital, No. 201, Sec 2, Shi-Pai Road, Taipei 112, Taiwan

${ }^{2}$ Department of Orthopaedics, School of Medicine, National Yang-Ming Chiao-Tung University, Taipei, Taiwan

Full list of author information is available at the end of the article
}

(c) The Author(s). 2021 Open Access This article is licensed under a Creative Commons Attribution 4.0 International License, which permits use, sharing, adaptation, distribution and reproduction in any medium or format, as long as you give appropriate credit to the original author(s) and the source, provide a link to the Creative Commons licence, and indicate if changes were made. The images or other third party material in this article are included in the article's Creative Commons licence, unless indicated otherwise in a credit line to the material. If material is not included in the article's Creative Commons licence and your intended use is not permitted by statutory regulation or exceeds the permitted use, you will need to obtain permission directly from the copyright holder. To view a copy of this licence, visit http://creativecommons.org/licenses/by/4.0/ The Creative Commons Public Domain Dedication waiver (http://creativecommons.org/publicdomain/zero/1.0/) applies to the data made available in this article, unless otherwise stated in a credit line to the data. 
Conclusion: Modern dual-mobility designs provide satisfactory mid-term implant survival and clinical performance. Younger age and female patients might impact the outcome after DM-THA. Future research directions should focus on, (1) long-term outcome of modern dual-mobility design, including specific concerns such as intra-prosthetic dislocation and elevated metal ion, and (2) cost-effectiveness analysis of dual-mobility implant as an alternative to conventional THA for patients who are at high risk of dislocation.

Keywords: Dislocation, Dual mobility, Implant failure, Instability, Outcome, Revision total hip arthroplasty, Risk factor, Total hip arthroplasty

\section{Background}

Prosthetic dislocation is one of the most common cause of implant failure after total hip arthroplasty (THA) [1]. The reported dislocation rate after primary THAs is 0.3$10 \%$ [2-4] and is much higher after revision THAs (530\%) [5-7]. The cause of a dislocated prosthesis can be multifactorial, including both surgeon and patient related factors [8-18]. Several design changes have been made on the prosthesis to resolve this. Currently, dual mobility (DM) THA is one of the most successful designs to reduce the risk of dislocation [19]. The concept of DM was invented by Gilles Bousquet and Andrè Rambert in France in 1973 [19]. The design included Charnley's low-friction principle and the theory of McKee and Watson-Farrar, which increased the femoral head-toneck ratio, extending the "jumping" distance in order to prevent dislocations [20-23]. The first generation DM design was associated with higher aseptic loosening and intra-prosthetic dislocation (IPD) rate, which resulted from polyethylene wear, suboptimal fixation and surface coating of the acetabular component [24-30]. In the late 1990's, a newer DM design was introduced with several modifications including modular design, shape, surface coating and highly cross-linked polyethylene to reduce the rate of aseptic loosening and IPD [31-34].

Compared with the fixed-bearing THA, several metaanalyses have validated a lower dislocation rate using DM articulation in both primary [35-37] and revision THA procedures [36-39]. Despite the established efficacy of DM articulation in preventing dislocation, it is with clinical importance to validate the overall implant survival and failure modes of this unique design. These studies could only provide results of inferential statistics rather than descriptive statistics with regard to the outcome after DM-THA because the included studies represented only a small number of DM-THA used in primary and revision THA procedures [36-39]. To our knowledge, the most recent and comprehensive systematic review discussing the outcome after DM-THA was conducted by Darrith et al. [40] The authors reviewed studies published from 2007 to 2016, including 54 studies with 14345 primary and revision THA procedures. They reported the overall failure rate (primary: $2.0 \%$, revision: $3.4 \%$ ) and incidence of common failure modes including aseptic loosening (primary: 1.3\%, revision: $1.4 \%$ ), extra-articular dislocation (primary: $0.46 \%$, revision: $2.2 \%$ ) and intra-prosthetic dislocation (primary: $1.1 \%$, revision: $0.3 \%$ ). However, this review included a mixture of the $1^{\text {st }}$ generation and modern $\left(2^{\text {nd }}\right.$ and $3^{\text {rd }}$ generations) DM designs. Several important modes of implant failure such as septic loosening and periprosthetic fracture were not analyzed in this review. Moreover, the number of articles regarding the outcome of modern DM-THA have doubled since 2016 [41-115]. Therefore, an up-to-date meta-analysis is essential to validate the outcome of modern DM-THA. Our primary objective was to identify the overall implant failure rate and several common failure modes including aseptic loosening, septic loosening, extra-articular dislocation, intra-prosthetic dislocation and periprosthetic fracture. The secondary objective was to determine risk factors predisposing to implant failure and the functional performance of these patients after surgery.

\section{Methods}

We completed a comprehensive search on PubMed, MEDLINE, Cochrane Reviews and Embase for studies that reported outcome in patients who had undergone dual mobility total hip arthroplasty (DM-THA) published from the earliest record to August, 2020. The search was completed in accordance to the Preferred Reporting Items for Systematic Reviews and Metaanalysis (PRISMA) statement. The following terms were used in variable combinations: total hip arthroplasty, total hip replacement and dual mobility. Two authors (FYP, SWT) independently searched and screened the titles and abstracts for relevant studies. If there was disagreement, a third author (HHM) was consulted for a consensus. The bibliographies of the included studies were manually reviewed for relevant references. The search strategy is shown in Fig. 1.

We included original articles written in English that validated the outcome in patients who had undergone DM-THA for all kinds of indications including primary THA, revision THA or recurrent dislocation. We excluded review articles, letter to the editor, expert opinion, biomechanical studies, articles not written in English, study period earlier than 2000 or studies in 


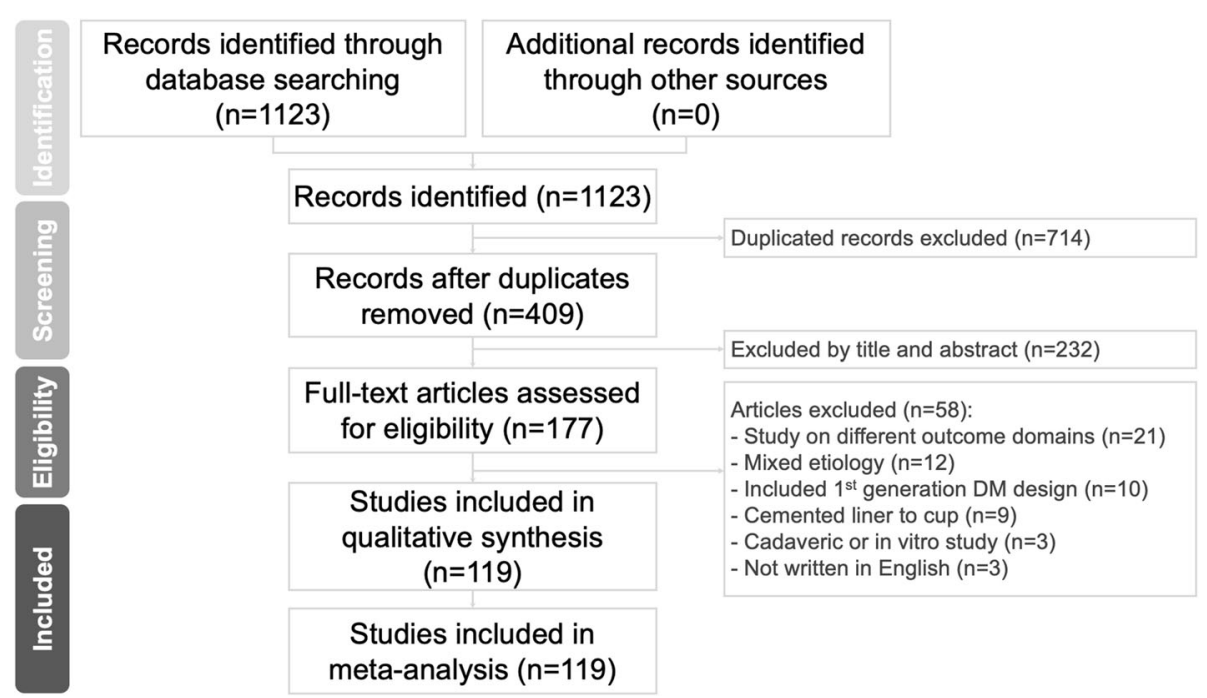

Fig. 1 Preferred reporting items for systematic reviews and meta-analysis (PRISMA) flow diagram for the searching and identification of included studies

which data were not obtainable. The included studies must contain at least one of the primary (e.g. overall implant failure rate, failure modes including aseptic loosening, septic loosening, extra-articular dislocation, intraprosthetic dislocation and periprosthetic fracture) or secondary outcome domains (e.g. functional scores). Two authors (FYP, SWT) examined all relevant studies and obtained data from the texts. If none of the above outcome domains can be obtained from the study, then we will exclude the study. For comparative studies (e.g. hemiarthroplasty or THA vs DM-THA), we extracted data from the DM-THA group if possible. If there was uncertainty regarding the data from the study, we contacted the authors for clarifications.

Two authors (FYP, SWT) examined all relevant studies and extracted data using a predetermined form. The primary aim was to determine the overall implant failure rate and failure modes including aseptic loosening, septic loosening, extra-articular dislocation, intra-prosthetic dislocation and periprosthetic fracture. We further validated these rates stratified by indications including primary THA, revision THA for all causes or for recurrent dislocation. The secondary aim was to identify risk factors for implant failures and to evaluate the functional outcome using Harris hip score [116] and Merle d'Aubigné score [117]. We recorded the first author, year, study design, number of THA procedures, indications, age, follow-up duration, implant brand and outcome parameters in Table 1.

Two authors (FYP, SWT) independently evaluated the methodological quality of the included studies using the NIH Quality Assessment Tool for Case Series Studies and Case Control Studies [118, 119]. To assess the quality of case series study, the highest score on this scale is 9. A score between 7 and 9, 4 and 6, less than 4 were defined as "good", "fair" and "poor", respectively. For the quality of case control study, the highest score on this scale is 12 . A score between 8 and 12, 5 and 7, less than 5 were defined as "good", "fair" and "poor", respectively. If there were disagreement, we consulted a third author (HHM). (Tables 2 and 3) Of the 119 included studies, the methodological quality was considered "good" in $72(60.5 \%)$ studies and "fair" in 47 (39.5\%) studies.

\section{Statistical analysis}

A meta-analysis of proportions was conducted using the Freeman-Tukey analysis under random-effects model to determine pooled estimates with a $95 \%$ confidence interval (CI). A random-effects model was used for differences among studies such as age, sex, surgical approaches, body mass index, indications for THA procedure, implant brand and methodology. A standard multivariate linear regression analysis $(\beta)$ was performed to determine potential factors for implant failure or improved functional outcome. We completed all analyses with the Comprehensive Meta-Analysis (CMA) software, version 3 (Biostat, Englewood, New Jersey, USA) and significance was defined as $\mathrm{p}<0.05$.

\section{Results}

We identified 1123 studies according to our search strategy. We removed 714 duplicate records and 232 studies after reading the title and abstract. Another 58 studies were excluded after reading the full text as the studies did not meet the inclusion criteria: studies on different 
Table 1 Characteristics of included studies

\begin{tabular}{|c|c|c|c|c|c|c|c|c|c|c|c|c|c|}
\hline Author, Year & Study design & $\begin{array}{l}\text { No. of THA } \\
\text { procedure }\end{array}$ & Indications & $\begin{array}{l}\text { Mean age } \\
\text { (yrs) }\end{array}$ & $\begin{array}{l}\text { Follow up duration } \\
(\mathrm{m})\end{array}$ & $\begin{array}{l}\text { Implant } \\
\text { type }\end{array}$ & A & B & C & D & & $F C$ & \\
\hline 2020 Tabori-jensen & $\begin{array}{l}\text { Prospective } \\
\text { series }\end{array}$ & 59 & Primary & 75 & 24 & 1 & V & V & V & V & v & V & / \\
\hline 2020 Schmidt & $\begin{array}{l}\text { Retrospective } \\
\text { series }\end{array}$ & 184 & Revision & 69 & 24 & 2,3 & V & V & v & v & V & V & \\
\hline 2020 Rashed & $\begin{array}{l}\text { Prospective } \\
\text { series }\end{array}$ & 31 & Primary & 66.4 & 12 & 4 & & & v & v & & & / \\
\hline 2020 Nessler & $\begin{array}{l}\text { Retrospective } \\
\text { series }\end{array}$ & 93 & Primary & 65.5 & 32.4 & 5 & V & V & v & v & V & & \\
\hline 2020 Laende & $\begin{array}{l}\text { Retrospective } \\
\text { series }\end{array}$ & 27 & Primary & 63 & 36 & 6 & V & V & v & v & v & V & \\
\hline 2020 Klemt & $\begin{array}{l}\text { Retrospective } \\
\text { series }\end{array}$ & 42 & Revision & 55 & 48 & $\begin{array}{l}1,5,6,10 \\
13\end{array}$ & V & V & v & v & v & V & \\
\hline 2020 Hoggett & $\begin{array}{l}\text { Retrospective } \\
\text { series }\end{array}$ & 28 & $\begin{array}{l}\text { Recurrent } \\
\text { dislocation }\end{array}$ & 80 & 55 & 3,7 & V & V & v & v & v & V & \\
\hline 2020 Favreau & $\begin{array}{l}\text { Retrospective } \\
\text { series }\end{array}$ & 40 & Revision & 77 & 54 & 3 & V & V & v & V & v & V & \\
\hline 2020 Dubin & $\begin{array}{l}\text { Retrospective } \\
\text { series }\end{array}$ & 664 & Primary & 61.7 & 25 & 5,6 & V & V & v & V & V & V & / \\
\hline $\begin{array}{l}2020 \text { Dubin (Arthroplasty } \\
\text { Today) }\end{array}$ & $\begin{array}{l}\text { Retrospective } \\
\text { series }\end{array}$ & 142 & Primary & 67 & 68.4 & 6 & V & V & v & V & V & V & \\
\hline 2020 de l'Escalopier & $\begin{array}{l}\text { Retrospective } \\
\text { series }\end{array}$ & 84 & Revision & 71 & 65.3 & 8,9 & V & V & v & V & V & V & \\
\hline 2020 Colacchio & $\begin{array}{l}\text { Retrospective } \\
\text { series }\end{array}$ & 29 & Revision & 61.4 & 47 & 6,10 & V & V & v & V & V & V & \\
\hline 2020 Civinini & $\begin{array}{l}\text { Retrospective } \\
\text { series }\end{array}$ & 37 & Revision & 63.7 & 61.2 & 5 & & & & & & & d \\
\hline 2020 Ait Mokhtar & $\begin{array}{l}\text { Retrospective } \\
\text { series }\end{array}$ & 148 & Primary & 78 & 38 & 2 & V & V & v & V & V & V & \\
\hline 2020 Abdel & $\begin{array}{l}\text { Retrospective } \\
\text { series }\end{array}$ & 126 & Revision & 66 & 43.2 & 5 & V & V & v & V & V & V & \\
\hline 2019 Ukaj & $\begin{array}{l}\text { Prospective } \\
\text { series }\end{array}$ & 47 & Primary & 78.1 & 36 & 2 & V & V & v & v & V & V & / \\
\hline 2019 Tabori-jensen, Arch & $\begin{array}{l}\text { Retrospective } \\
\text { series }\end{array}$ & 997 & Primary & 80.5 & 64.8 & 1,11 & V & V & v & V & V & V & \\
\hline 2019 Schmidt-braekling & $\begin{array}{l}\text { Retrospective } \\
\text { series }\end{array}$ & 77 & Revision & 68.5 & 63.6 & 1,4 & V & V & v & V & V & V & v \\
\hline 2019 Nonne & $\begin{array}{l}\text { Retrospective } \\
\text { series }\end{array}$ & 60 & Primary & 87.6 & 28.3 & 12 & V & V & v & V & V & V & / \\
\hline 2019 Neil Wheelton & $\begin{array}{l}\text { Retrospective } \\
\text { series }\end{array}$ & 54 & Revision & 78 & 22.8 & NR & V & V & v & V & V & V & \\
\hline $2019 \mathrm{Nam}$ & $\begin{array}{l}\text { Prospective } \\
\text { series }\end{array}$ & 43 & Primary & 52.6 & 24 & 5 & & & & & & & / \\
\hline 2019 Markel & $\begin{array}{l}\text { Prospective } \\
\text { series }\end{array}$ & 21 & Primary & 61.7 & 24 & 5 & & & & & & & y \\
\hline $2019 \mathrm{Li}$ & $\begin{array}{l}\text { Retrospective } \\
\text { series }\end{array}$ & 94 & Revision & 63.6 & 37.8 & 5 & & & v & v & & V & \\
\hline 2019 Kreipke & $\begin{array}{l}\text { Retrospective } \\
\text { series }\end{array}$ & 2277 & Primary & 75.5 & 35.9 & $1,11,13$ & V & V & v & V & V & V & \\
\hline 2019 Jones & $\begin{array}{l}\text { Retrospective } \\
\text { series }\end{array}$ & 151 & Primary & 82 & 43.2 & 6 & V & V & v & V & V & V & \\
\hline 2019 Jobory & $\begin{array}{l}\text { Retrospective } \\
\text { series }\end{array}$ & 4520 & Primary & 77 & 25.2 & $1,11,13$ & V & V & & & V & V & \\
\hline 2019 lorio & $\begin{array}{l}\text { Retrospective } \\
\text { series }\end{array}$ & 30 & Primary & 82 & 12 & 2 & V & V & v & V & V & V & \\
\hline 2019 Huang & $\begin{array}{l}\text { Retrospective } \\
\text { series }\end{array}$ & 315 & Revision & 65.8 & 39.6 & 5 & V & V & v & V & v & V & / \\
\hline 2019 Huang & $\begin{array}{l}\text { Retrospective } \\
\text { series }\end{array}$ & 107 & $\begin{array}{l}\text { Recurrent } \\
\text { dislocation }\end{array}$ & 65.8 & 39.6 & 5 & & & V & V & & & \\
\hline
\end{tabular}


Table 1 Characteristics of included studies (Continued)

\begin{tabular}{|c|c|c|c|c|c|c|c|c|c|c|c|c|c|}
\hline Author, Year & Study design & $\begin{array}{l}\text { No. of THA } \\
\text { procedure }\end{array}$ & Indications & $\begin{array}{l}\text { Mean age } \\
\text { (yrs) }\end{array}$ & $\begin{array}{l}\text { Follow up duration } \\
(\mathrm{m})\end{array}$ & $\begin{array}{l}\text { Implant } \\
\text { type }\end{array}$ & A & B & C & D & $E$ & $F C$ & $G \quad$ \\
\hline 2019 Gaillard & $\begin{array}{l}\text { Retrospective } \\
\text { series }\end{array}$ & 138 & Primary & 68 & 152.4 & 11 & V & V & V & V & V & V V & V V \\
\hline 2019 Fessy & $\begin{array}{l}\text { Retrospective } \\
\text { series }\end{array}$ & 541 & Primary & 73.6 & 103.2 & 3 & V & V & V & V & V & V V & \\
\hline 2019 Fahad & $\begin{array}{l}\text { Retrospective } \\
\text { series }\end{array}$ & 27 & Primary & 69.3 & 19 & NR & & & V & V & v & v & \\
\hline 2019 Dubin & $\begin{array}{l}\text { Retrospective } \\
\text { series }\end{array}$ & 287 & Primary & 67.8 & 34.3 & 6 & V & V & V & V & V & V V & \\
\hline 2019 Dubin & $\begin{array}{l}\text { Retrospective } \\
\text { series }\end{array}$ & 287 & Primary & 67.9 & 34.3 & 5 & V & V & V & V & V & V V & \\
\hline 2019 Dikmen & $\begin{array}{l}\text { Prospective } \\
\text { series }\end{array}$ & 34 & Revision & 66.1 & 42.24 & 13 & V & V & V & V & V & V V & \\
\hline 2019 Cypres & $\begin{array}{l}\text { Retrospective } \\
\text { series }\end{array}$ & 244 & Primary & 63.8 & 142.8 & 13 & V & V & V & V & V & V & $v$ \\
\hline 2019 Chalmers & $\begin{array}{l}\text { Retrospective } \\
\text { series }\end{array}$ & 24 & Revision & 63 & 48 & 5 & & & & & & v & \\
\hline 2019 Canton & $\begin{array}{l}\text { Retrospective } \\
\text { series }\end{array}$ & 31 & Primary & 76.7 & 67.2 & 1 & V & V & V & V & & v & \\
\hline 2019 Boulat & $\begin{array}{l}\text { Retrospective } \\
\text { series }\end{array}$ & 33 & Primary & 74 & 44 & 3 & V & V & V & V & V & V V & $v V$ \\
\hline 2019 Bloemheuvel & $\begin{array}{l}\text { Retrospective } \\
\text { series }\end{array}$ & 3038 & Primary & 70 & 36 & $\begin{array}{l}1,2,11,13 \\
14\end{array}$ & V & V & V & V & V & v & \\
\hline 2019 Bloemheuvel & $\begin{array}{l}\text { Retrospective } \\
\text { series }\end{array}$ & 4637 & Revision & 74 & 72 & $\begin{array}{l}1,2,11,13 \\
14\end{array}$ & V & V & & & V & v & \\
\hline 2019 Assi(J Arthroplasty) & $\begin{array}{l}\text { Retrospective } \\
\text { series }\end{array}$ & 125 & Primary & 78.1 & 61.2 & 1,2 & V & V & V & V & & v & \\
\hline 2019 Assi(Int Orthop) & $\begin{array}{l}\text { Retrospective } \\
\text { series }\end{array}$ & 16 & Revision & 69.2 & 72.9 & NR & V & V & V & V & V & $\vee v$ & \\
\hline 2019 Assi(Hip Int.) & $\begin{array}{l}\text { Retrospective } \\
\text { series }\end{array}$ & 229 & Primary & 62 & 70 & 1,2 & V & V & V & v & v & $\vee v$ & \\
\hline 2019 Addona & $\begin{array}{l}\text { Retrospective } \\
\text { series }\end{array}$ & 107 & Primary & NR & NR & $5 ; 15$ & & & V & V & & v & \\
\hline 2019 Addona & $\begin{array}{l}\text { Retrospective } \\
\text { series }\end{array}$ & 47 & Revision & NR & NR & $5 ; 15$ & & & V & v & & v & \\
\hline 2018 Tabori-Jensen & $\begin{array}{l}\text { Retrospective } \\
\text { series }\end{array}$ & 124 & Primary & 74.7 & 33.6 & 11 & V & V & V & v & V & $\vee v$ & \\
\hline 2018 Stucinskas & $\begin{array}{l}\text { Retrospective } \\
\text { series }\end{array}$ & 247 & Revision & 72 & 24 & $1 ; 2$ & V & V & V & v & V & v & \\
\hline 2018 Spaans & $\begin{array}{l}\text { Retrospective } \\
\text { series }\end{array}$ & 102 & $\begin{array}{l}\text { Recurrent } \\
\text { dislocation }\end{array}$ & 73.1 & 27.6 & 1 & V & V & V & v & V & v & \\
\hline 2018 Rashed & $\begin{array}{l}\text { Prospective } \\
\text { series }\end{array}$ & 32 & Primary & 66.4 & 12 & 4 & V & V & V & V & V & $\vee v$ & \\
\hline 2018 Perrin & $\begin{array}{l}\text { Prospective } \\
\text { series }\end{array}$ & 24 & Revision & 79.5 & 6 & NR & V & V & V & v & V & V & \\
\hline 2018 Ozden & $\begin{array}{l}\text { Retrospective } \\
\text { series }\end{array}$ & 20 & Revision & 64.5 & 38.1 & 13 & V & V & V & V & V & V V & \\
\hline 2018 Marie-hardy & $\begin{array}{l}\text { Retrospective } \\
\text { series }\end{array}$ & 16 & Primary & 69.6 & 29 & 3 & V & V & V & V & V & v & $v$ \\
\hline 2018 Lange & $\begin{array}{l}\text { Retrospective } \\
\text { series }\end{array}$ & 40 & $\begin{array}{l}\text { Recurrent } \\
\text { dislocation }\end{array}$ & 64 & 36 & $5 ; 6$ & V & V & V & V & V & v & \\
\hline 2018 Kim & $\begin{array}{l}\text { Retrospective } \\
\text { series }\end{array}$ & 84 & Primary & 73.1 & 21.7 & 5 & & & V & v & & v & \\
\hline 2018 Kavcic & $\begin{array}{l}\text { Retrospective } \\
\text { series }\end{array}$ & 173 & Primary & 76.8 & 92.4 & 1 & V & V & V & v & V & $\vee V$ & \\
\hline 2018 Kasparek & $\begin{array}{l}\text { Retrospective } \\
\text { series }\end{array}$ & 11 & Revision & 64 & 31 & $5 ; 6$ & V & V & V & V & V & $\vee v$ & \\
\hline 2018 Hwang & $\begin{array}{l}\text { Prospective } \\
\text { series }\end{array}$ & 167 & Primary & 72 & 22 & 10 & V & v & V & V & V & $\vee v$ & \\
\hline
\end{tabular}


Table 1 Characteristics of included studies (Continued)

\begin{tabular}{|c|c|c|c|c|c|c|c|c|c|c|c|c|c|}
\hline Author, Year & Study design & $\begin{array}{l}\text { No. of THA } \\
\text { procedure }\end{array}$ & Indications & $\begin{array}{l}\text { Mean age } \\
\text { (yrs) }\end{array}$ & $\begin{array}{l}\text { Follow up duration } \\
\text { (m) }\end{array}$ & $\begin{array}{l}\text { Implant } \\
\text { type }\end{array}$ & A & B & C & $D E$ & $E F$ & $G$ & $\mathrm{H}$ \\
\hline 2018 Harwin & $\begin{array}{l}\text { Retrospective } \\
\text { series }\end{array}$ & 85 & Revision & 67 & 48 & 5 & V & v & v & V V & V V & V V & \\
\hline 2018 Hartzler & $\begin{array}{l}\text { Retrospective } \\
\text { series }\end{array}$ & 126 & Revision & 66 & 40 & 5 & & & v & V & v & & \\
\hline 2018 Diamond & $\begin{array}{l}\text { Retrospective } \\
\text { series }\end{array}$ & 60 & Revision & 65.5 & 38.6 & 5 & V & v & v & V V & $\mathrm{V} V$ & & \\
\hline 2018 Chalmers & $\begin{array}{l}\text { Retrospective } \\
\text { series }\end{array}$ & 14 & $\begin{array}{l}\text { Recurrent } \\
\text { dislocation }\end{array}$ & 65 & 37 & 5 & V & v & v & V V & V V & / V & \\
\hline 2018 Boukebous & $\begin{array}{l}\text { Retrospective } \\
\text { series }\end{array}$ & 98 & Primary & 77.8 & 25.9 & 16,17 & & & v & V & & & \\
\hline 2018 Assi & $\begin{array}{l}\text { Retrospective } \\
\text { series }\end{array}$ & 30 & Primary & 54.9 & 51 & $1 ; 2 ; 19$ & V & v & v & $\vee v$ & I V & / V & \\
\hline 2017 Viste & $\begin{array}{l}\text { Retrospective } \\
\text { series }\end{array}$ & 334 & Revision & NR & 84 & 3 & V & v & v & V V & V V & & \\
\hline 2017 Tarasevicius & $\begin{array}{l}\text { Retrospective } \\
\text { series }\end{array}$ & 620 & Revision & 63.2 & 30 & $1 ; 2$ & V & v & v & V V & V V & & \\
\hline 2017 Sutter & $\begin{array}{l}\text { Retrospective } \\
\text { series }\end{array}$ & 64 & Revision & 59 & 38 & 5 & V & v & v & V V & V V & & \\
\hline 2017 Rowan & $\begin{array}{l}\text { Retrospective } \\
\text { series }\end{array}$ & 136 & Primary & 48.5 & 38.4 & $5 ; 6$ & V & v & v & V V & & / V & \\
\hline 2017 Puch & $\begin{array}{l}\text { Prospective } \\
\text { series }\end{array}$ & 103 & Primary & 49.9 & 132 & 20 & V & v & v & V V & V V & / v & V \\
\hline 2017 Puch & $\begin{array}{l}\text { Prospective } \\
\text { series }\end{array}$ & 217 & Primary & 72.3 & 149 & 20 & V & v & v & $\vee v$ & $\mathrm{~V} V$ & / v & V \\
\hline 2017 Ochi & $\begin{array}{l}\text { Retrospective } \\
\text { series }\end{array}$ & 33 & Primary & 80 & 15.8 & 5 & V & V & v & V V & V & & \\
\hline $2017 \mathrm{Nam}$ & $\begin{array}{l}\text { Prospective } \\
\text { series }\end{array}$ & 26 & Primary & 52.8 & 12 & 5 & & & & & & V & \\
\hline 2017 Martz & $\begin{array}{l}\text { Retrospective } \\
\text { series }\end{array}$ & 25 & Primary & 44 & 129.8 & 3 & V & v & v & V V & V V & / V & V \\
\hline 2017 Lebeau & $\begin{array}{l}\text { Retrospective } \\
\text { series }\end{array}$ & 62 & Revision & 75.5 & 77 & 2 (1st-gen) & V & v & v & V v & V & / V & V \\
\hline 2017 Hernigou & $\begin{array}{l}\text { Retrospective } \\
\text { series }\end{array}$ & 35 & Revision & 73 & 84 & 2,21 & V & v & v & $\vee v$ & V V & & V \\
\hline 2017 Henawy & $\begin{array}{l}\text { Prospective } \\
\text { series }\end{array}$ & 24 & Primary & 68 & 12 & 3 & V & v & v & v v & & / v & V \\
\hline 2017 Hamadouche & $\begin{array}{l}\text { Retrospective } \\
\text { series }\end{array}$ & 51 & Revision & 71.4 & 60 & 8 & V & v & v & v v & $V V$ & & V \\
\hline 2017 Graversen & $\begin{array}{l}\text { Retrospective } \\
\text { series }\end{array}$ & 20 & Primary & 83 & 12 & 1 & V & V & V & V V & I V & & \\
\hline 2017 Gonzalez & $\begin{array}{l}\text { Prospective } \\
\text { series }\end{array}$ & 150 & Revision & 73 & 6 & $13 ; 22$ & V & V & V & V v & / V & & \\
\hline 2017 Ferreira & $\begin{array}{l}\text { Retrospective } \\
\text { series }\end{array}$ & 553 & Primary & 71.2 & 36 & 2 & V & V & V & V v & IV & & \\
\hline 2017 Ferreira & $\begin{array}{l}\text { Retrospective } \\
\text { series }\end{array}$ & 83 & Primary & 81.7 & 36 & 2 & V & v & v & $\vee v$ & $\mathrm{~V} V$ & & \\
\hline 2017 Epinette & $\begin{array}{l}\text { Retrospective } \\
\text { series }\end{array}$ & 321 & Primary & 48.1 & 32.4 & 5,6 & v & V & v & V v & V & / V & \\
\hline 2017 Chalmers & $\begin{array}{l}\text { Retrospective } \\
\text { series }\end{array}$ & 16 & Revision & 75 & 36 & 5 & V & v & v & $\vee v$ & V V & / v & \\
\hline 2017 Batailler & $\begin{array}{l}\text { Retrospective } \\
\text { series }\end{array}$ & 302 & Primary & 73 & 14 & 2,23 & V & v & v & v v & $\mathrm{V} V$ & / $v$ & V \\
\hline 2016 Nich & $\begin{array}{l}\text { Retrospective } \\
\text { series }\end{array}$ & 45 & Primary & 86.7 & 23.8 & $6 ; 24$ & V & v & v & V v & V V & & V \\
\hline 2016 Morin & $\begin{array}{l}\text { Retrospective } \\
\text { series }\end{array}$ & 40 & Primary & 19.2 & 60 & NR & V & v & v & $\vee v$ & V V & & \\
\hline 2016 Jauregui & $\begin{array}{l}\text { Retrospective } \\
\text { series }\end{array}$ & 60 & Revision & 57 & 30 & 5 & V & v & v & V v & V & / V & \\
\hline
\end{tabular}


Table 1 Characteristics of included studies (Continued)

\begin{tabular}{|c|c|c|c|c|c|c|c|c|c|c|c|c|c|}
\hline Author, Year & Study design & $\begin{array}{l}\text { No. of THA } \\
\text { procedure }\end{array}$ & Indications & $\begin{array}{l}\text { Mean age } \\
\text { (yrs) }\end{array}$ & $\begin{array}{l}\text { Follow up duration } \\
(\mathrm{m})\end{array}$ & $\begin{array}{l}\text { Implant } \\
\text { type }\end{array}$ & A & B & $C \mathrm{D}$ & D E & $E F$ & G & $\mathrm{H}$ \\
\hline 2016 Homma & $\begin{array}{l}\text { Retrospective } \\
\text { series }\end{array}$ & 60 & Primary & 75.6 & 6 & $5 ; 6$ & $\mathrm{~V}$ & $\mathrm{~V}^{\prime}$ & $v v$ & $V \vee$ & $V \vee$ & & \\
\hline 2016 Haughom & $\begin{array}{l}\text { Retrospective } \\
\text { series }\end{array}$ & 24 & Primary & 50.2 & 3 & NR & & & $\vee v$ & v & & & \\
\hline 2016 Griffin & $\begin{array}{l}\text { Prospective } \\
\text { series }\end{array}$ & 10 & Primary & $>60$ & 12 & 3 & V & v & $\vee v$ & $\vee v$ & $\vee \vee$ & & \\
\hline 2016 Chughtai & $\begin{array}{l}\text { Retrospective } \\
\text { series }\end{array}$ & 410 & Primary & 64 & 36 & 5 & V & v & $\vee v$ & $\vee v$ & $\vee \vee$ & V & \\
\hline 2016 Carulli & $\begin{array}{l}\text { Retrospective } \\
\text { series }\end{array}$ & 31 & $\begin{array}{l}\text { Recurrent } \\
\text { dislocation }\end{array}$ & 75.4 & 45.6 & 1 & V & v & $\vee v$ & $\vee v$ & $\vee \vee$ & V & \\
\hline 2015 Wegrzyn & $\begin{array}{l}\text { Retrospective } \\
\text { series }\end{array}$ & 994 & Revision & 70 & 87.6 & 11 & V & v & $\vee v$ & v & & & \\
\hline 2015 Vigdorchik & $\begin{array}{l}\text { Retrospective } \\
\text { series }\end{array}$ & 485 & Primary & 66 & 24 & 6 & V & v & $\vee v$ & V V & $\vee \vee$ & V & \\
\hline 2015 Vermersch & $\begin{array}{l}\text { Prospective } \\
\text { series }\end{array}$ & 86 & Primary & 72 & 27 & 3 & V & v & $\vee v$ & V V & $\vee \vee$ & V & V \\
\hline 2015 van Heumen & $\begin{array}{l}\text { Retrospective } \\
\text { series }\end{array}$ & 50 & $\begin{array}{l}\text { Recurrent } \\
\text { dislocation }\end{array}$ & 67 & 29 & 1 & V & v & $\vee v$ & V V & $\vee \vee$ & & \\
\hline 2015 Snir & $\begin{array}{l}\text { Retrospective } \\
\text { series }\end{array}$ & 18 & Revision & 50.6 & 26.5 & $5 ; 6 ; 10$ & V & v & $\vee v$ & V V & $\vee \vee$ & V & \\
\hline 2015 Simian & $\begin{array}{l}\text { Retrospective } \\
\text { series }\end{array}$ & 74 & Revision & 67.9 & 87.6 & $17 ; 18 ; 25$ & V & v & $\vee v$ & V V & $\vee \vee$ & V & V \\
\hline 2015 Mohammed & $\begin{array}{l}\text { Retrospective } \\
\text { series }\end{array}$ & 20 & Primary & 70.8 & 22 & NR & V & v & $\vee v$ & V V & $\vee \vee$ & & \\
\hline 2015 Mohammed & $\begin{array}{l}\text { Retrospective } \\
\text { series }\end{array}$ & 24 & Revision & 76.4 & 22 & NR & V & V & $\vee v$ & V V & $V \vee$ & & \\
\hline 2015 Epinette & $\begin{array}{l}\text { Prospective } \\
\text { series }\end{array}$ & 143 & Primary & 70.6 & 50 & 6 & V & v & $\vee v$ & V V & $\vee \vee$ & V & V \\
\hline 2015 Bel & $\begin{array}{l}\text { Retrospective } \\
\text { series }\end{array}$ & 18 & Primary & 84 & 36 & 3 & V & v & v v & V V & $\vee V$ & & \\
\hline 2014 Wegrzyn & $\begin{array}{l}\text { Prospective } \\
\text { series }\end{array}$ & 61 & Revision & 67 & 86 & 11 & V & v & v v & V V & $\vee \vee$ & V & \\
\hline 2014 Prudhon & $\begin{array}{l}\text { Prospective } \\
\text { series }\end{array}$ & 79 & Revision & 62.5 & 24 & 7 & V & v & v v & V V & $\vee \vee$ & & \\
\hline 2014 Jakobsen & $\begin{array}{l}\text { Retrospective } \\
\text { series }\end{array}$ & 56 & $\begin{array}{l}\text { Recurrent } \\
\text { dislocation }\end{array}$ & 72 & 44 & 11 & V & v & v v & V V & $\vee \vee$ & V & \\
\hline 2014 Epinette & $\begin{array}{l}\text { Prospective } \\
\text { series }\end{array}$ & 437 & Primary & 74.2 & 24 & 6 & V & v & v v & V V & & V & V \\
\hline 2014 Caton & $\begin{array}{l}\text { Retrospective } \\
\text { series }\end{array}$ & 105 & Primary & 78 & 120 & 2 & V & v & v v & V V & $\vee \vee$ & & \\
\hline 2014 Bensen & $\begin{array}{l}\text { Retrospective } \\
\text { series }\end{array}$ & 175 & Primary & 75.2 & 21.7 & 11 & V & v & $\vee v$ & V V & $\vee \vee$ & & \\
\hline 2013 Tarasevicius & $\begin{array}{l}\text { Retrospective } \\
\text { series }\end{array}$ & 41 & Primary & 75 & 12 & 1 & V & V & V V & V V & $V \vee$ & & \\
\hline 2013 Saragaglia & $\begin{array}{l}\text { Retrospective } \\
\text { series }\end{array}$ & 29 & $\begin{array}{l}\text { Recurrent } \\
\text { dislocation }\end{array}$ & 75.6 & 46 & $1 ; 3 ; 20 ; 24$ & V & v & $\vee v$ & $\vee v$ & $\vee \vee$ & & v \\
\hline 2013 Sanders & $\begin{array}{l}\text { Retrospective } \\
\text { series }\end{array}$ & 10 & Primary & 54 & 39 & 1 & V & V & V & V V & $V \vee$ & & \\
\hline 2013 Prudhon & $\begin{array}{l}\text { Retrospective } \\
\text { series }\end{array}$ & 105 & Primary & 78 & 91 & 2 & V & v & v & $\vee v$ & $\vee \vee$ & & V \\
\hline 2012 Vasukutty & $\begin{array}{l}\text { Retrospective } \\
\text { series }\end{array}$ & 143 & Revision & 77 & 42 & NR & V & v & v v & $\vee v$ & $\vee \vee$ & & \\
\hline 2012 Pattyn & $\begin{array}{l}\text { Retrospective } \\
\text { series }\end{array}$ & 36 & Revision & 70 & 16 & 26 & V & v & $\vee v$ & $\vee v$ & $\vee \vee$ & & \\
\hline 2012 Hamadouche & $\begin{array}{l}\text { Retrospective } \\
\text { series }\end{array}$ & 119 & Primary & 67 & 72 & 9 & V & v & $\vee v$ & V & & & V \\
\hline 2012 Hailer & $\begin{array}{l}\text { Retrospective } \\
\text { series }\end{array}$ & 228 & $\begin{array}{l}\text { Recurrent } \\
\text { dislocation }\end{array}$ & 75 & 24 & 1 & V & v & $\vee v$ & $\vee v$ & $\vee \vee$ & & \\
\hline
\end{tabular}


Table 1 Characteristics of included studies (Continued)

\begin{tabular}{|c|c|c|c|c|c|c|c|c|c|c|c|c|c|c|}
\hline Author, Year & Study design & $\begin{array}{l}\text { No. of THA } \\
\text { procedure }\end{array}$ & Indications & $\begin{array}{l}\text { Mean age } \\
\text { (yrs) }\end{array}$ & $\begin{array}{l}\text { Follow up duration } \\
(\mathrm{m})\end{array}$ & $\begin{array}{l}\text { Implant } \\
\text { type }\end{array}$ & A & B & $C$ & D & E & F & G & $\bar{H}$ \\
\hline 2012 Civinini & $\begin{array}{l}\text { Prospective } \\
\text { series }\end{array}$ & 33 & Revision & 69 & 36 & 1 & $\mathrm{~V}$ & $\mathrm{~V}$ & $\mathrm{~V}$ & V & $\mathrm{V}$ & V V & $\mathrm{V}$ & \\
\hline 2012 Adam & $\begin{array}{l}\text { Prospective } \\
\text { series }\end{array}$ & 214 & Primary & 83 & 9 & NR & V & V & V & V & V & V & & \\
\hline 2011 Schneider & $\begin{array}{l}\text { Retrospective } \\
\text { series }\end{array}$ & 96 & Revision & 69.9 & 41 & 3 & V & V & V & V & V & V & & V \\
\hline 2011 Bouchet & $\begin{array}{l}\text { Retrospective } \\
\text { series }\end{array}$ & 105 & Primary & 76.6 & 28 & $1 ; 3 ; 20 ; 24$ & & & V & V & & V & & \\
\hline 2010 Tarasevicius & $\begin{array}{l}\text { Retrospective } \\
\text { series }\end{array}$ & 42 & Primary & 75 & 12 & 1 & & & V & V & & V & & \\
\hline 2010 Hamadouche & $\begin{array}{l}\text { Retrospective } \\
\text { series }\end{array}$ & 47 & $\begin{array}{l}\text { Recurrent } \\
\text { dislocation }\end{array}$ & 71.3 & 51.4 & 8 & V & V & V & V & V & V & & V \\
\hline 2009 Guyen & $\begin{array}{l}\text { Retrospective } \\
\text { series }\end{array}$ & 54 & $\begin{array}{l}\text { Recurrent } \\
\text { dislocation }\end{array}$ & 66.5 & 48 & 11 & V & V & V & V & V & $\vee v$ & V & \\
\hline 2008 Langlais & $\begin{array}{l}\text { Retrospective } \\
\text { series }\end{array}$ & 88 & Revision & 72 & 36 & 8 & V & V & V & V & V & V & & V \\
\hline 2008 Bauchu & $\begin{array}{l}\text { Retrospective } \\
\text { series }\end{array}$ & 121 & Primary & 69 & 74.4 & 13 & V & V & V & V & V & V & & V \\
\hline
\end{tabular}

A: aseptic loosening; B; septic loosening or PJl; C: extra-dislocation; D: Intra-dislocation; E: Periprosthetic fracture; F: implant failure; G; HHS; H: Merle

D'Aubigne scores

1: Avantage (Zimmer Biomet, Warsaw, Indiana, USA); 2: Quattro (Groupe Lépine, Genay, France ); 3. Novae cup or Novae Sunfit cup (Serf, Décines, France); 4. EcoFit 2M cup (Ecofit, implantcast, Buxtehude, Germany); 5. Stryker MDM (Stryker, Mahwah, New Jersey, USA); 6. Stryker ADM (Stryker, Mahwah, New Jersey, USA); 7. ADES (Zimmer Biomet, Warsaw, Indiana, USA); 8. Medial cup (Aston Medical, Saint-Étienne, France); 9. Tregor cup (Aston Medical, Saint-Étienne, France); 10. Biomet Active Articulation E1 (Biomet Orthopedics, Warsaw, Indiana, USA); 11. Saturne (Amplitude, Valence, France); 12. Dualis acetabular cup (Gruppo Bioimpianti, Peschiera Borromeo, Milano, Italy); 13. Polarcup (Smith \& Nephew AG, Aarau, Switzerland); 14. SeleXys DS cup (Mathys European Orthopaedics, Bettlach,

Switzerland); 15. G7 DM (Zimmer Biomet, Warsaw, Indiana, USA); 16. Galiléa (SEM, Créteil, France); 17. Evora (SEM, Créteil, France); 18. DMS (SEM, Créteil, France); 19. Hip'n Go dual mobility (FH orthopedics, Mulhouse, France); 20. Gyros cup (Depuy, Warsaw, IN, USA); 21. Ceraver DM device (Ceraver Osteal, Roissy, France); 22. Versafit DM cup (Medacata international, Castel San Pietro, Switzerland); 23. Tornier DM cup (Tornier, Montbonnot-Saint-Martin, France); 24. Stafit (Zimmer, Etupes, France); 25. Mobilite (Tornier, Montbonnot-Saint-Martin, France); 26. Apogee DM socket (Biotechni Inc., Marseille, France)

outcome domains $(n=21)$, mixed etiologies $(n=12)$, 1st generation DM designs $(\mathrm{n}=10)$, cemented liner to cup $(n=9)$, cadaveric or in vitro studies $(n=3)$, studies not written in English $(n=3)$. After exclusion, a total of 119 studies were included [41-115, 120-163] (Figure 1). Of these studies, 45 were case-control studies while 74 were case series. Since the objectives of this study were to validate the risk factors and modes of failures in the modern dual mobility implants, we extracted only the dual mobility group but not the control group from the 45 case-control studies.

\section{Baseline characteristics}

This study included 30016 patients who had undergone DM-THA for primary and revision THA procedures. The mean age was 71.9 years (range, 19.2 to 87.6) and $63.2 \%$ of the patients were female. Mean follow-up duration in overall, primary, revision and recurrent dislocation group were 47.29 months (range, 3 to 152.4 ), 40.86 months (range, 3 to 152.4), 61.82 months (range, 6 to 87.6), and 35.23 months (range, 24 to 55), respectively. DM-THA was used in 19819 primary THA procedures, 9411 revision THA procedures and 786 revision THA procedures for recurrent dislocation.

\section{Aseptic loosening}

A total of 105 studies, including 28980 DM-THA procedures, reported the rate of aseptic loosening. The pooled rate was $1.6 \%$ (95\% CI 0.008 - 0.032). The aseptic loosening rate in primary THA, revision THA and revision THA for recurrent dislocation were $0.9 \%, 2.2 \%$ and $2.4 \%$, respectively (Table 4 , Figure S1). A multivariate regression analysis revealed that a revision THA procedure for all causes $(\beta=1.30,95 \%$ CI $0.71-1.89)$, or for recurrent dislocation $(\beta=1.18$, $95 \%$ CI 0.26 - 2.10), carried a higher risk of aseptic loosening compared with a primary THA procedure (Table 5).

\section{Septic loosening}

A total of 105 studies, including 28980 DM-THA procedures, reported septic loosening rates. The pooled rate was $1.6 \%$ (95\% CI 0.007 - 0.037). The septic loosening rate in primary THA, revision THA and revision THA procedure for recurrent dislocation were $0.8 \%, 2.3 \%$ and $2.5 \%$, respectively (Table 4 , Figure $\mathrm{S} 2$ ). A multivariate regression analysis showed that both revision THA for all causes $(\beta=1.85,95 \%$ CI $1.26-2.44)$ and for recurrent dislocation $(\beta=1.40,95 \%$ CI $0.45-2.36)$ were at a higher risk of septic loosening, compared with a primary THA procedure (Table 5). 


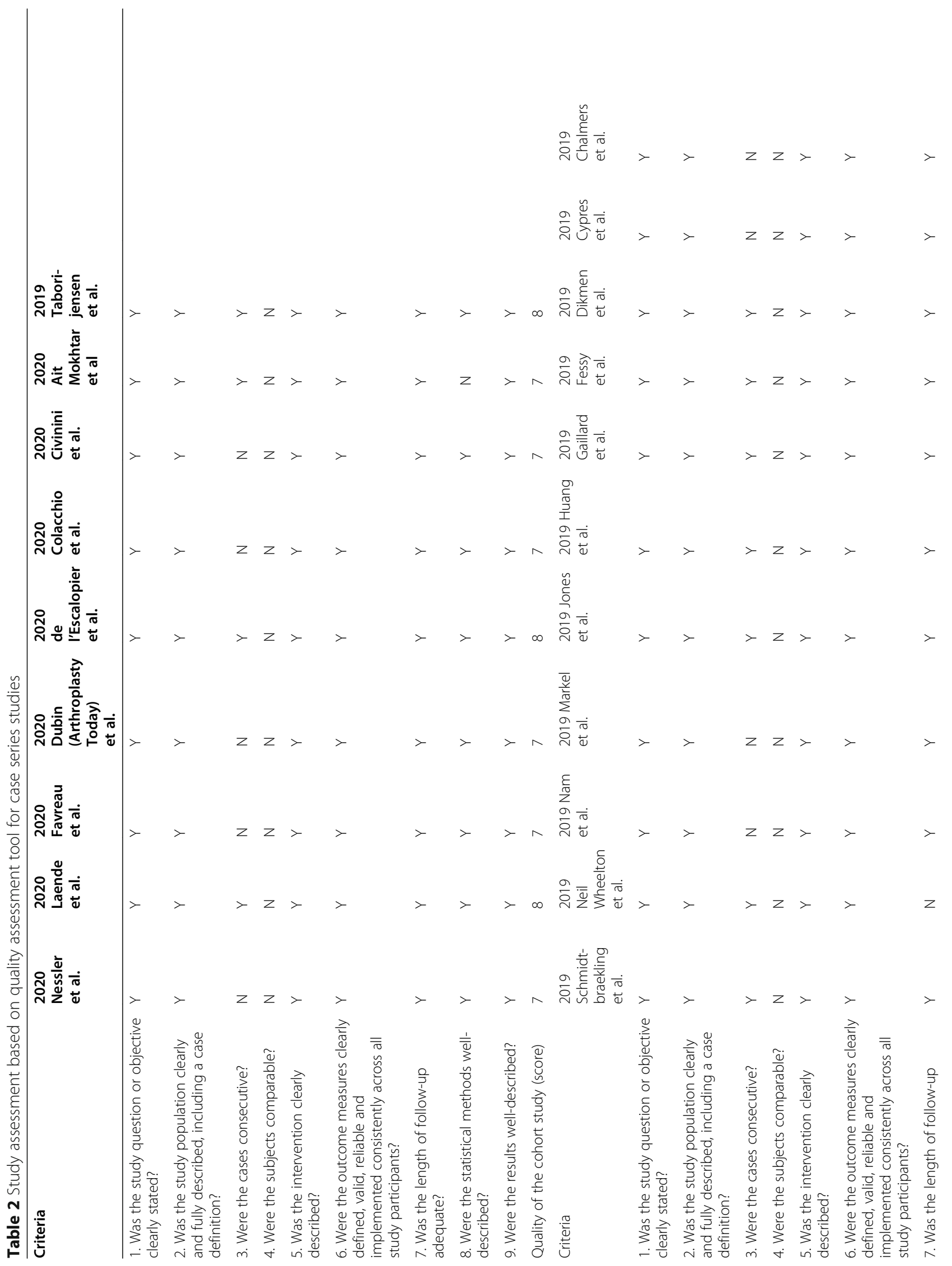




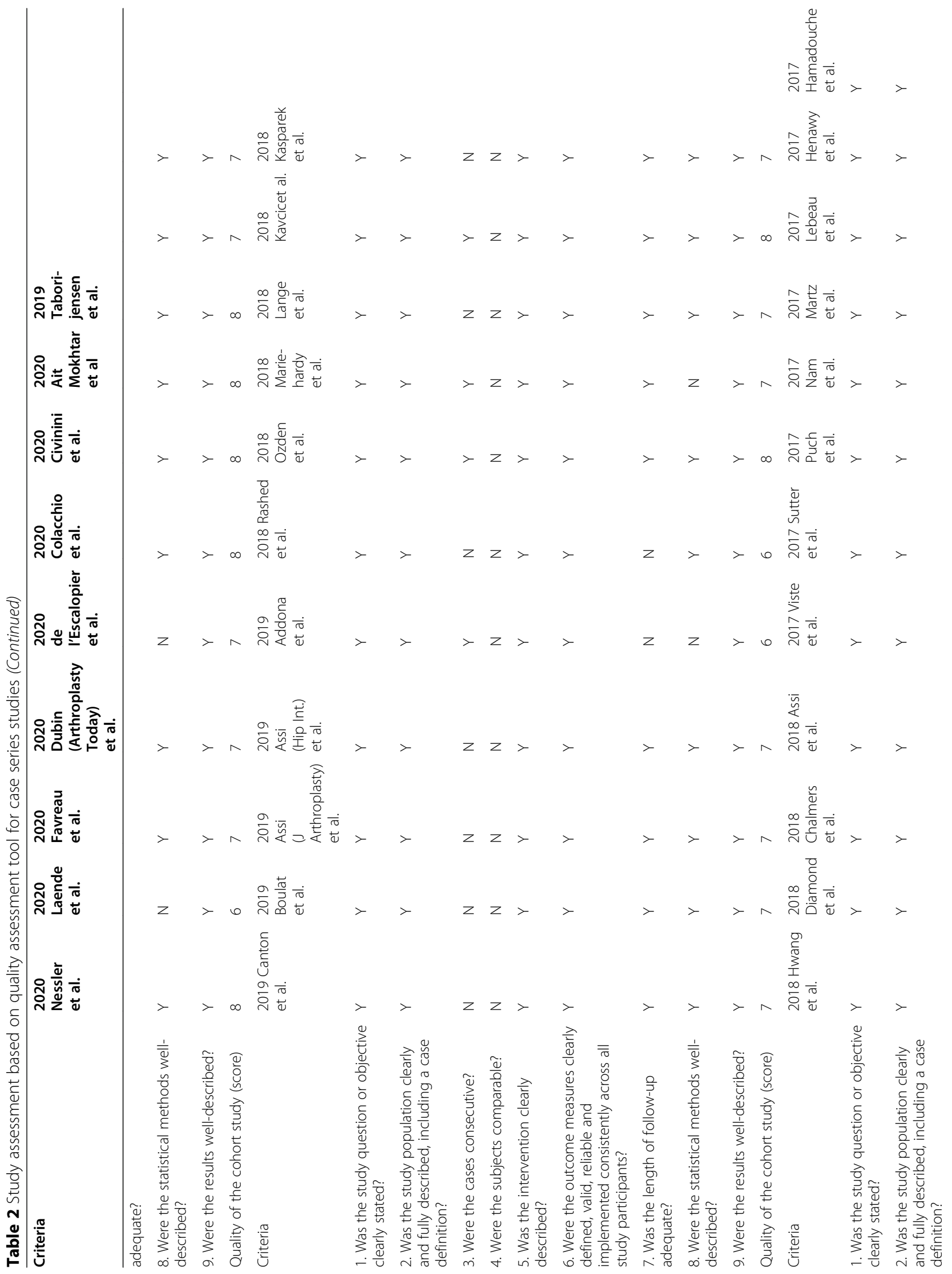




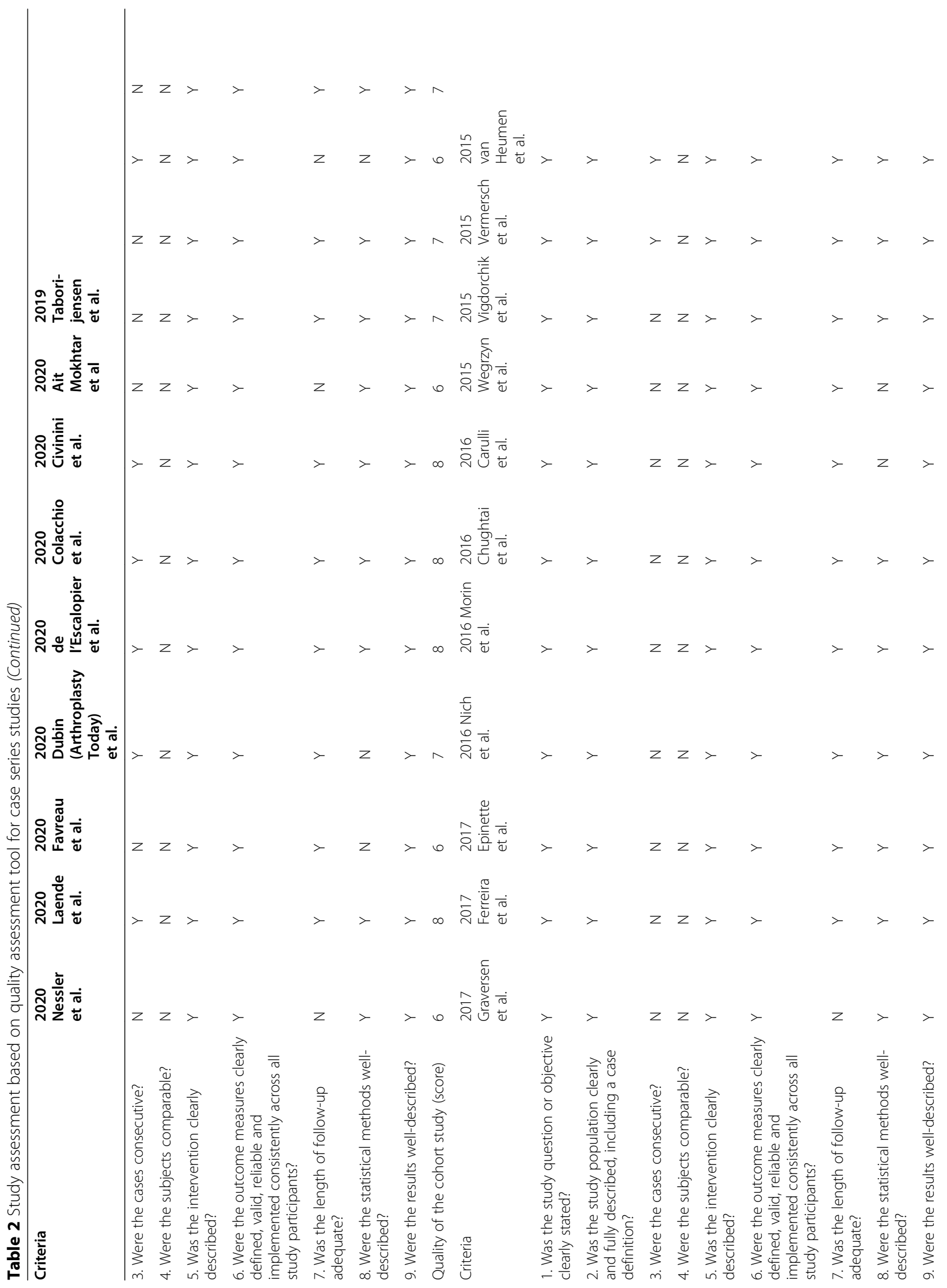




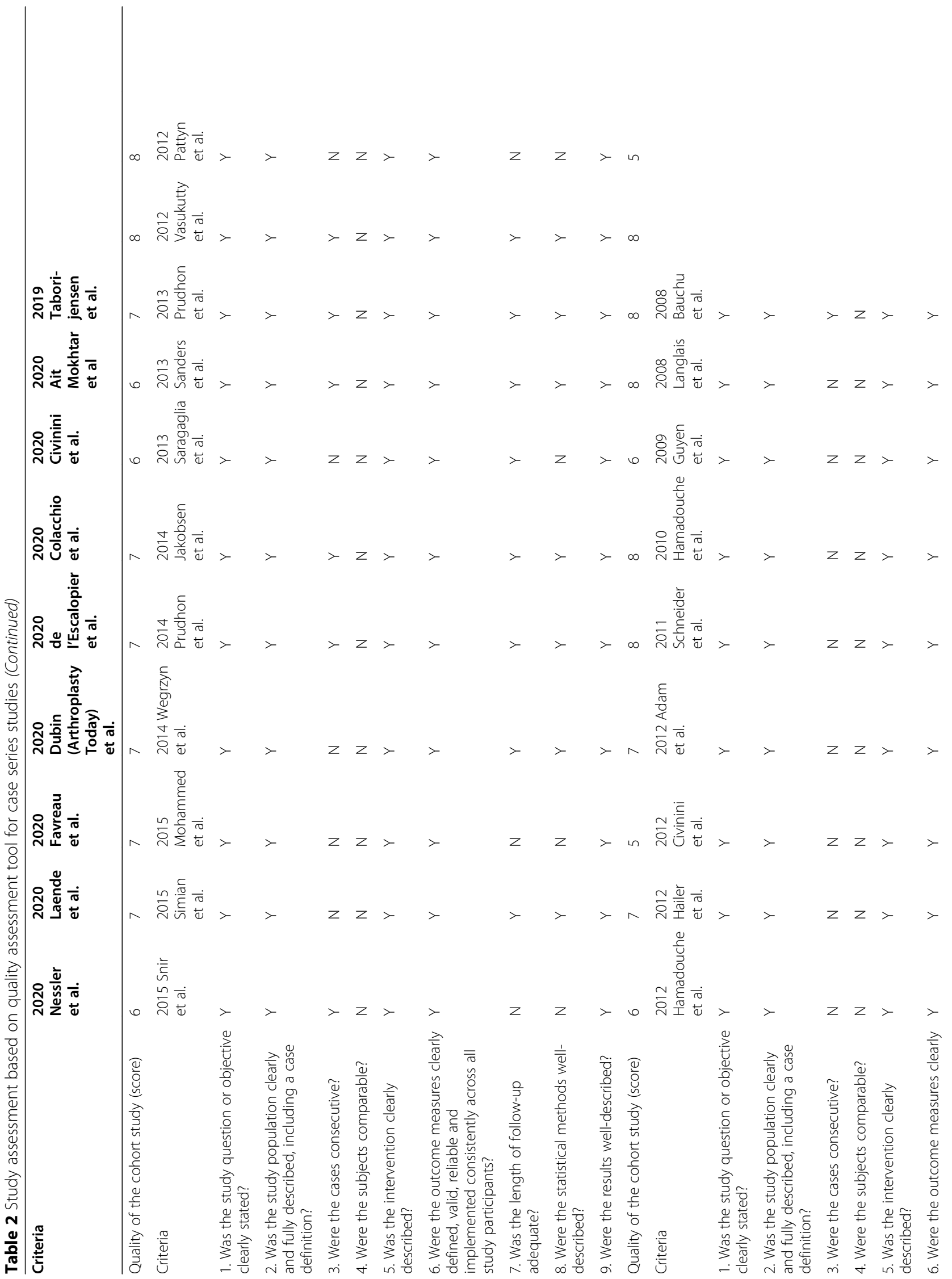




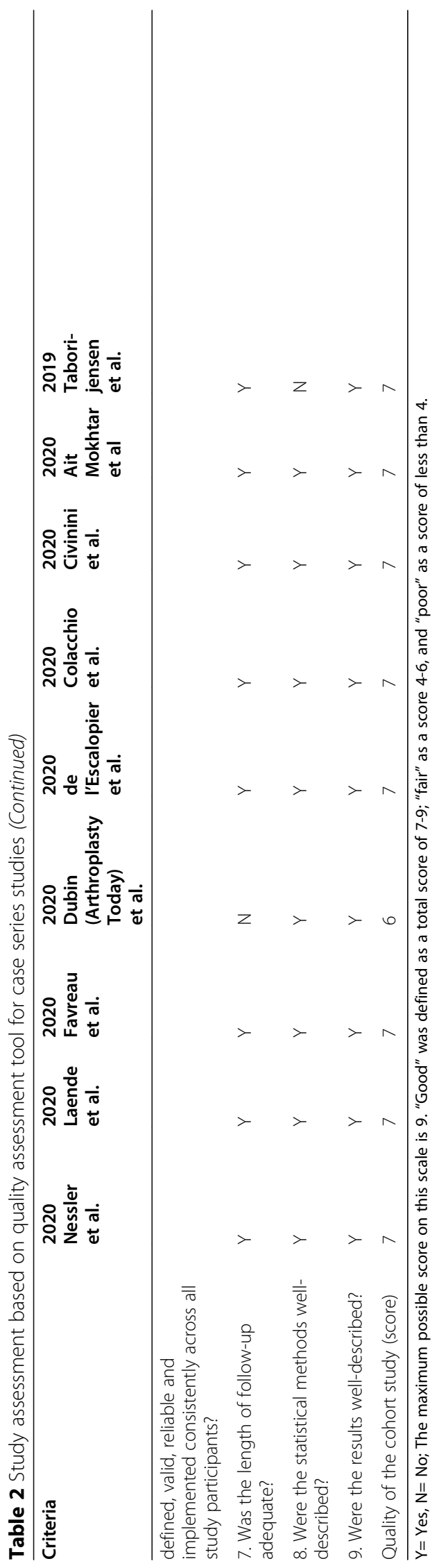


Table 3 Study assessment based on quality assessment tool for case control studies

\begin{tabular}{llllllll}
\hline Criteria & 2020 & 2020 & 2020 & 2020 & 2020 & 2020 & 2020 \\
& $\begin{array}{l}\text { Tabori- } \\
\text { jensen }\end{array}$ & $\begin{array}{l}\text { Schmidt } \\
\text { et al. }\end{array}$ & $\begin{array}{l}\text { Rashed } \\
\text { et al. }\end{array}$ & $\begin{array}{l}\text { Klemt } \\
\text { et al }\end{array}$ & $\begin{array}{l}\text { Hoggett } \\
\text { et al. }\end{array}$ & $\begin{array}{l}\text { Dubin } \\
\text { et al. }\end{array}$ & $\begin{array}{l}\text { Abdel } \\
\text { et al }\end{array}$
\end{tabular}

1. Was the research question or objective in $Y$

et al. this paper clearly stated and appropriate?

2. Was the study population clearly specified $Y$ and defined?

3. Did the authors include a sample size $\quad$ Y justification?

4. Were controls selected or recruited from $\quad Y$ the same or similar population that gave rise to the cases (including the same timeframe)?

5. Were the definitions, inclusion and Y exclusion criteria, algorithms or processes used to identify or select cases and controls valid, reliable, and implemented consistently across all study participants?

6. Were the cases clearly defined and $\quad Y$ differentiated from controls?

7. If less than 100 percent of eligible cases $\quad Y$ and/or controls were selected for the study, were the cases and/or controls randomly selected from those eligible?

8. Was there use of concurrent controls?

9. Were the investigators able to confirm that the exposure/risk occurred prior to the development of the condition or event that defined a participant as a case?

10. Were the measures of exposure/risk clearly defined, valid, reliable, and implemented consistently (including the same time period) across all study participants?

11. Were the assessors of exposure/risk blinded to the case or control status of participants?

12. Were key potential confounding variables $N$ measured and adjusted statistically in the analyses? If matching was used, did the investigators account for matching during study analysis?

Quality of the cohort study (score)

Criteria

1. Was the research question or objective in $Y$ this paper clearly stated and appropriate?

2. Was the study population clearly specified $Y$ and defined?

3. Did the authors include a sample size $\quad$ Y justification?

4. Were controls selected or recruited from $\quad Y$ the same or similar population that gave rise to the cases (including the same timeframe)?

5. Were the definitions, inclusion and exclusion criteria, algorithms or processes used to identify or select cases and controls valid, reliable, and implemented consistently

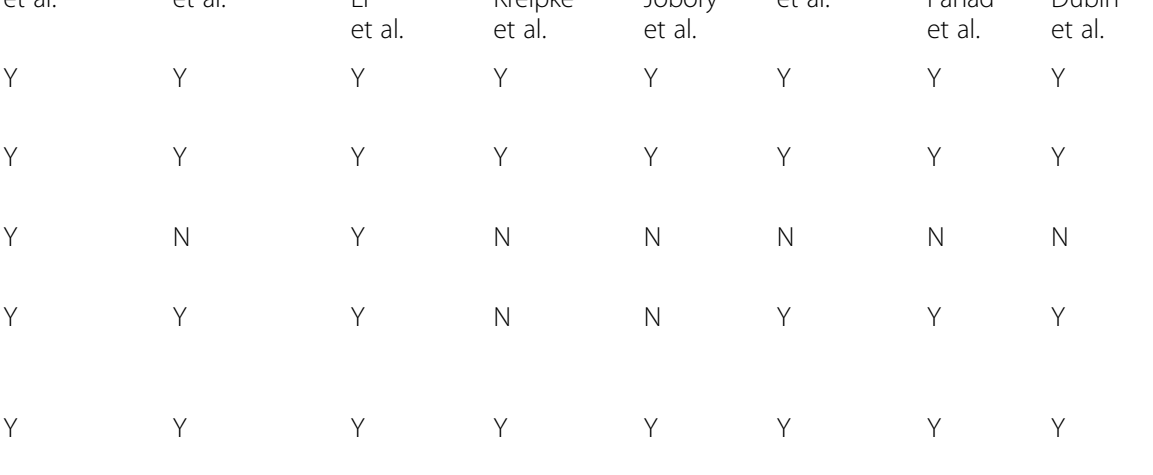


Table 3 Study assessment based on quality assessment tool for case control studies (Continued)

\begin{tabular}{llllllll}
\hline Criteria & 2020 & 2020 & 2020 & 2020 & 2020 & 2020 & 2020 \\
& $\begin{array}{l}\text { Tabori- } \\
\text { jensen }\end{array}$ & $\begin{array}{l}\text { Schmidt } \\
\text { et al. }\end{array}$ & $\begin{array}{l}\text { Rashed } \\
\text { et al. }\end{array}$ & $\begin{array}{l}\text { Klemt } \\
\text { et al }\end{array}$ & $\begin{array}{l}\text { Hoggett } \\
\text { et al. }\end{array}$ & $\begin{array}{l}\text { Dubin } \\
\text { et al. }\end{array}$ & $\begin{array}{l}\text { Abdel } \\
\text { et al }\end{array}$
\end{tabular}

across all study participants?

6. Were the cases clearly defined and $Y$ differentiated from controls?

7. If less than 100 percent of eligible cases $\quad Y$
and/or controls were selected for the study,

Y $\quad$ Y

Y $\quad Y$

Y

Y

Y

Y

Y

N

N

N

N

Y

N

were the cases and/or controls randomly

selected from those eligible?

8. Was there use of concurrent controls? NR

9. Were the investigators able to confirm $\quad Y$ that the exposure/risk occurred prior to the development of the condition or event that defined a participant as a case?

10. Were the measures of exposure/risk clearly defined, valid, reliable, and implemented consistently (including the same time period) across all study participants?

11. Were the assessors of exposure/risk blinded to the case or control status of

Y participants?

12. Were key potential confounding variables $\mathrm{N}$ measured and adjusted statistically in the analyses? If matching was used, did the investigators account for matching during study analysis?

Quality of the cohort study (score)

Criteria

1. Was the research question or objective in this paper clearly stated and appropriate?

2. Was the study population clearly specified $Y$ and defined?

3. Did the authors include a sample size $\quad N$ justification?

4. Were controls selected or recruited from N the same or similar population that gave rise to the cases (including the same timeframe)?

5. Were the definitions, inclusion and Y exclusion criteria, algorithms or processes used to identify or select cases and controls valid, reliable, and implemented consistently across all study participants?

6. Were the cases clearly defined and differentiated from controls?

7. If less than 100 percent of eligible cases and/or controls were selected for the study, were the cases and/or controls randomly selected from those eligible?

8. Was there use of concurrent controls?

9. Were the investigators able to confirm that the exposure/risk occurred prior to the development of the condition or event that

10

Y

$\begin{array}{llllllll}N R & N R & N R & N R & N R & N R & N R & N R \\ Y & Y & Y & Y & Y & Y & Y & Y\end{array}$

Y $\quad$ Y

N

N

Y

Y

Y

N

N

N

N

N

N

N

N

N

N

N

N

N

N

$7 \quad 8$

\section{5}

5

8

7

7

20192019

Bloemheuvel,

2019 Assi

2018

van Steenbergen

Steenbergen et al.

Assi
(Int

Tabori-

2018

2018

Stucinskas Spaans

2018

Perrin

2018

Jensen

et al.

et al.

et al.

Kim

et al.

et al.

Y $\quad Y$

Y Y

Y

Y

Y

Y

Y

Y

Y

Y

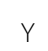

Y

Y

Y

Y

N N

N

N

N

N

N

N

Y

Y

Y

Y

Y

Y

Y

Y

Y

Y

Y $\quad Y$

Y

N

N

N

N

N

N

N

NR

NR

NR

NR
$Y$

NR

NR

NR

NR

Y

Y

Y

Y

Y

Y 
Table 3 Study assessment based on quality assessment tool for case control studies (Continued)

\begin{tabular}{llllllll}
\hline Criteria & 2020 & 2020 & 2020 & 2020 & 2020 & 2020 & 2020 \\
& $\begin{array}{l}\text { Tabori- } \\
\text { jensen }\end{array}$ & $\begin{array}{l}\text { Schmidt } \\
\text { et al. }\end{array}$ & $\begin{array}{l}\text { Rashed } \\
\text { et al. }\end{array}$ & $\begin{array}{l}\text { Klemt } \\
\text { et al }\end{array}$ & $\begin{array}{l}\text { Hoggett } \\
\text { et al. }\end{array}$ & $\begin{array}{l}\text { Dubin } \\
\text { et al. }\end{array}$ & $\begin{array}{l}\text { Abdel } \\
\text { et al }\end{array}$
\end{tabular}

defined a participant as a case?

10. Were the measures of exposure/risk

et al.

clearly defined, valid, reliable, and

N

et al.

et al.

et al

et al.

et al.

et al

implemented consistently (including the

same time period) across all study

participants?

11. Were the assessors of exposure/risk

N

N

N

blinded to the case or control status of participants?

12. Were key potential confounding variables $N$ measured and adjusted statistically in the analyses? If matching was used, did the investigators account for matching during study analysis?

Quality of the cohort study (score)

Criteria

2018 Harwin 2018 Hartzler et al. et al.

1. Was the research question or objective in $Y$ this paper clearly stated and appropriate?

2. Was the study population clearly specified $Y$ and defined?

3. Did the authors include a sample size N justification?

4. Were controls selected or recruited from $\quad$ Y the same or similar population that gave rise to the cases (including the same timeframe)?

5. Were the definitions, inclusion and Y exclusion criteria, algorithms or processes used to identify or select cases and controls valid, reliable, and implemented consistently across all study participants?

6. Were the cases clearly defined and differentiated from controls?

7. If less than 100 percent of eligible cases and/or controls were selected for the study, were the cases and/or controls randomly selected from those eligible?

8. Was there use of concurrent controls?

9. Were the investigators able to confirm $N R$

NR

Y

that the exposure/risk occurred prior to the development of the condition or event that defined a participant as a case?

10. Were the measures of exposure/risk clearly defined, valid, reliable, and implemented consistently (including the same time period) across all study participants?

11. Were the assessors of exposure/risk blinded to the case or control status of participants? 12. Were key potential confounding variables $N$ measured and adjusted statistically in the analyses? If matching was used, did the investigators account for matching during study analysis?

Y

Y

N

Y

Y

Y

N

Y

Y

N

Non

N

$\begin{array}{llllll}N & N & N & N & N & \text { N }\end{array}$

$\begin{array}{lll}\text { Boukebous } & \text { Tarasevicius } & \text { Rowan } \\ \text { et al. } & \text { et al. } & \text { et al. }\end{array}$

N

N

N

N

N

N

N

N

N

N

N

N 
Table 3 Study assessment based on quality assessment tool for case control studies (Continued)

\begin{tabular}{|c|c|c|c|c|c|c|c|c|}
\hline Criteria & $\begin{array}{l}2020 \\
\text { Tabori- } \\
\text { jensen } \\
\text { et al. }\end{array}$ & $\begin{array}{l}2020 \\
\text { Schmidt } \\
\text { et al. }\end{array}$ & $\begin{array}{l}2020 \\
\text { Rashed } \\
\text { et al. }\end{array}$ & $\begin{array}{l}2020 \\
\text { Klemt } \\
\text { et al }\end{array}$ & $\begin{array}{l}2020 \\
\text { Hoggett } \\
\text { et al. }\end{array}$ & $\begin{array}{l}2020 \\
\text { Dubin } \\
\text { et al. }\end{array}$ & $\begin{array}{l}2020 \\
\text { Abdel } \\
\text { et al }\end{array}$ & \\
\hline Quality of the cohort study (score) & 7 & 7 & 8 & 6 & 7 & 8 & 7 & 7 \\
\hline Criteria & $\begin{array}{l}2017 \\
\text { Chalmers } \\
\text { et al. }\end{array}$ & $\begin{array}{l}2017 \text { Batailler } \\
\text { et al. }\end{array}$ & $\begin{array}{l}2016 \\
\text { Jauregui } \\
\text { et al. }\end{array}$ & $\begin{array}{l}2016 \\
\text { Homma } \\
\text { et al. }\end{array}$ & $\begin{array}{l}2016 \\
\text { Haughom } \\
\text { et al. }\end{array}$ & $\begin{array}{l}2016 \text { Griffin } \\
\text { et al. }\end{array}$ & $\begin{array}{l}2015 \\
\text { Epinette } \\
\text { et al. }\end{array}$ & $\begin{array}{l}2015 \text { Bel } \\
\text { et al. }\end{array}$ \\
\hline $\begin{array}{l}\text { 1. Was the research question or objective in } \\
\text { this paper clearly stated and appropriate? }\end{array}$ & Y & Y & Y & Y & Y & Y & Y & Y \\
\hline $\begin{array}{l}\text { 2. Was the study population clearly specified } \\
\text { and defined? }\end{array}$ & Y & Y & Y & Y & Y & Y & Y & Y \\
\hline $\begin{array}{l}\text { 3. Did the authors include a sample size } \\
\text { justification? }\end{array}$ & N & N & N & N & Y & N & $N$ & $N$ \\
\hline $\begin{array}{l}\text { 4. Were controls selected or recruited from } \\
\text { the same or similar population that gave rise } \\
\text { to the cases (including the same timeframe)? }\end{array}$ & Y & Y & Y & Y & Y & Y & Y & Y \\
\hline $\begin{array}{l}\text { 5. Were the definitions, inclusion and } \\
\text { exclusion criteria, algorithms or processes } \\
\text { used to identify or select cases and controls } \\
\text { valid, reliable, and implemented consistently } \\
\text { across all study participants? }\end{array}$ & Y & Y & Y & Y & Y & Y & Y & Y \\
\hline $\begin{array}{l}\text { 6. Were the cases clearly defined and } \\
\text { differentiated from controls? }\end{array}$ & Y & Y & Y & Y & Y & Y & Y & Y \\
\hline $\begin{array}{l}\text { 7. If less than } 100 \text { percent of eligible cases } \\
\text { and/or controls were selected for the study, } \\
\text { were the cases and/or controls randomly } \\
\text { selected from those eligible? }\end{array}$ & $\mathrm{N}$ & N & N & N & $\mathrm{N}$ & Y & $\mathrm{N}$ & Y \\
\hline 8. Was there use of concurrent controls? & NR & NR & NR & NR & NR & NR & NR & NR \\
\hline $\begin{array}{l}\text { 9. Were the investigators able to confirm } \\
\text { that the exposure/risk occurred prior to the } \\
\text { development of the condition or event that } \\
\text { defined a participant as a case? }\end{array}$ & Y & Y & Y & Y & Y & Y & Y & Y \\
\hline $\begin{array}{l}\text { 10. Were the measures of exposure/risk } \\
\text { clearly defined, valid, reliable, and } \\
\text { implemented consistently (including the } \\
\text { same time period) across all study } \\
\text { participants? }\end{array}$ & Y & Y & Y & Y & Y & Y & Y & Y \\
\hline $\begin{array}{l}\text { 11. Were the assessors of exposure/risk } \\
\text { blinded to the case or control status of } \\
\text { participants? }\end{array}$ & $\mathrm{N}$ & N & N & $N$ & $N$ & Y & N & $N$ \\
\hline $\begin{array}{l}\text { 12. Were key potential confounding variables } \\
\text { measured and adjusted statistically in the } \\
\text { analyses? If matching was used, did the } \\
\text { investigators account for matching during } \\
\text { study analysis? }\end{array}$ & $\mathrm{N}$ & Y & N & N & N & N & $N$ & $N$ \\
\hline Quality of the cohort study (score) & 7 & 8 & 7 & 7 & 8 & 9 & 7 & 8 \\
\hline Criteria & $\begin{array}{l}2014 \\
\text { Epinette } \\
\text { et al. }\end{array}$ & $\begin{array}{l}2014 \text { Caton } \\
\text { et al. }\end{array}$ & $\begin{array}{l}2014 \\
\text { Bensen } \\
\text { et al. }\end{array}$ & $\begin{array}{l}2013 \\
\text { Tarasevicius } \\
\text { et al. }\end{array}$ & $\begin{array}{l}2011 \\
\text { Bouchet } \\
\text { et al. }\end{array}$ & $\begin{array}{l}2010 \\
\text { Tarasevicius } \\
\text { et al. }\end{array}$ & & \\
\hline $\begin{array}{l}\text { 1. Was the research question or objective in } \\
\text { this paper clearly stated and appropriate? }\end{array}$ & Y & Y & Y & $Y$ & Y & Y & & \\
\hline $\begin{array}{l}\text { 2. Was the study population clearly specified } \\
\text { and defined? }\end{array}$ & Y & Y & Y & Y & Y & $Y$ & & \\
\hline $\begin{array}{l}\text { 3. Did the authors include a sample size } \\
\text { justification? }\end{array}$ & $N$ & $N$ & $N$ & $Y$ & $N$ & $N$ & & \\
\hline $\begin{array}{l}\text { 4. Were controls selected or recruited from } \\
\text { the same or similar population that gave rise } \\
\text { to the cases (including the same timeframe)? }\end{array}$ & Y & Y & Y & Y & Y & Y & & \\
\hline
\end{tabular}


Table 3 Study assessment based on quality assessment tool for case control studies (Continued)

\begin{tabular}{|c|c|c|c|c|c|c|c|}
\hline Criteria & $\begin{array}{l}2020 \\
\text { Tabori- } \\
\text { jensen } \\
\text { et al. }\end{array}$ & $\begin{array}{l}2020 \\
\text { Schmidt } \\
\text { et al. }\end{array}$ & $\begin{array}{l}2020 \\
\text { Rashed } \\
\text { et al. }\end{array}$ & $\begin{array}{l}2020 \\
\text { Klemt } \\
\text { et al }\end{array}$ & $\begin{array}{l}2020 \\
\text { Hoggett } \\
\text { et al. }\end{array}$ & $\begin{array}{l}2020 \\
\text { Dubin } \\
\text { et al. }\end{array}$ & $\begin{array}{l}2020 \\
\text { Abdel } \\
\text { et al }\end{array}$ \\
\hline $\begin{array}{l}\text { 5. Were the definitions, inclusion and } \\
\text { exclusion criteria, algorithms or processes } \\
\text { used to identify or select cases and controls } \\
\text { valid, reliable, and implemented consistently } \\
\text { across all study participants? }\end{array}$ & Y & Y & Y & Y & Y & Y & \\
\hline $\begin{array}{l}\text { 6. Were the cases clearly defined and } \\
\text { differentiated from controls? }\end{array}$ & Y & Y & Y & Y & Y & Y & \\
\hline $\begin{array}{l}\text { 7. If less than } 100 \text { percent of eligible cases } \\
\text { and/or controls were selected for the study, } \\
\text { were the cases and/or controls randomly } \\
\text { selected from those eligible? }\end{array}$ & $\mathrm{N}$ & N & N & N & N & N & \\
\hline 8. Was there use of concurrent controls? & NR & NR & NR & NR & NR & NR & \\
\hline $\begin{array}{l}\text { 9. Were the investigators able to confirm } \\
\text { that the exposure/risk occurred prior to the } \\
\text { development of the condition or event that } \\
\text { defined a participant as a case? }\end{array}$ & Y & Y & Y & Y & Y & Y & \\
\hline $\begin{array}{l}\text { 10. Were the measures of exposure/risk } \\
\text { clearly defined, valid, reliable, and } \\
\text { implemented consistently (including the } \\
\text { same time period) across all study } \\
\text { participants? }\end{array}$ & Y & Y & Y & Y & Y & Y & \\
\hline $\begin{array}{l}\text { 11. Were the assessors of exposure/risk } \\
\text { blinded to the case or control status of } \\
\text { participants? }\end{array}$ & $\mathrm{N}$ & $\mathrm{N}$ & $\mathrm{N}$ & $\mathrm{N}$ & $\mathrm{N}$ & $\mathrm{N}$ & \\
\hline $\begin{array}{l}\text { 12. Were key potential confounding variables } \\
\text { measured and adjusted statistically in the } \\
\text { analyses? If matching was used, did the } \\
\text { investigators account for matching during } \\
\text { study analysis? }\end{array}$ & N & N & N & N & N & N & \\
\hline Quality of the cohort study (score) & 7 & 7 & 7 & 8 & 7 & 7 & \\
\hline
\end{tabular}

$\mathrm{Y}=\mathrm{Yes}, \mathrm{N}=\mathrm{No}$; The maximum possible score on this scale is 12. "Good" was defined as a total score of 8-12; "fair" as a score 5-7, and "poor" as a score of less than 5.

\section{Extra-articular dislocation}

A total of 113 studies, including 20447 DM-THA procedures, presented the extra-articular dislocation rate. The pooled rate was $1.2 \%$ (95\% CI $0.006-0.025)$. The extraarticular dislocation rate in primary THA, revision THA and revision THA for recurrent dislocation were $0.6 \%$, $1.3 \%$ and $2.5 \%$, respectively (Table 4 , Figure S3). Compared with a primary THA procedure, risk of dislocation was higher after revision THA procedures $(\beta=1.02,95 \%$ CI 0.30 - 1.73) (Table 5).

\section{Intra-prosthetic dislocation}

A total of 113 studies, including 20447 DM-THA procedures, reported the intra-prosthetic dislocation rate. The overall rate was $1.0 \%$ (95\% CI $0.007-0.015)$. The intraprosthetic dislocation rate in primary THA, revision THA and revision THA for recurrent dislocation were $0.8 \%, 1.0 \%$ and $1.6 \%$, respectively (Table 4, Figure S4). None of the factors including age, female sex, posterolateral approach, BMI or indication have led to intraprosthetic dislocation (Table 5).

\section{Periprosthetic fracture}

A total of 100 studies, including 27731 DM-THA procedures, recorded the periprosthetic fracture rate. The pooled rate was $0.9 \%$ (95\% CI $0.008-0.011)$. The periprosthetic fracture rates in primary THA, revision THA and revision THA for recurrent dislocation were $0.9 \%$, $0.9 \%$ and $1.3 \%$, respectively (Table 4 , Figure S5). Revision THA procedure for all causes $(\beta=0.93,95 \%$ CI $0.23-$ 1.62) was a risk factor for periprosthetic fracture (Table 5).

\section{Overall implant failure}

A total of 105 studies, including 27873 DM-THA procedures, recorded the implant failure rate. The pooled rate was $4.2 \%(95 \%$ CI $0.021-0.081)$ at a mean follow-up of 45.8 months. The implant failure rates in primary THA, revision THA and revision THA for recurrent dislocation were $2.3 \%, 5.5 \%$ and $6.0 \%$, respectively (Table 4, Figure S6). Younger age $(\beta=-0.04,95 \%$ CI $-0.07--0.02)$, female sex $(\beta=3.34,95 \%$ CI $0.91-5.78)$, revision THA procedure for all causes $(\beta=1.48,95 \%$ CI $0.93-2.03)$ 
Table 4 Pooled event rate and clinical performance stratified by indications

\begin{tabular}{|c|c|c|}
\hline & Rate or Mean Value & $95 \% \mathrm{Cl}$ \\
\hline \multicolumn{3}{|l|}{ Aseptic loosening } \\
\hline Primary THA & 0.009 & $0.007-0.012$ \\
\hline Revision THA & 0.022 & $0.016-0.030$ \\
\hline Recurrent dislocation & 0.024 & 0.013-0.045 \\
\hline Overall & 0.016 & $0.008-0.032$ \\
\hline \multicolumn{3}{|l|}{ Septic loosening } \\
\hline Primary THA & 0.008 & $0.006-0.011$ \\
\hline Revision THA & 0.023 & $0.017-0.032$ \\
\hline Recurrent dislocation & 0.025 & $0.013-0.049$ \\
\hline Overall & 0.016 & $0.007-0.037$ \\
\hline \multicolumn{3}{|l|}{ Extra-articular dislocation } \\
\hline Primary THA & 0.006 & $0.005-0.008$ \\
\hline Revision THA & 0.013 & $0.009-0.017$ \\
\hline Recurrent dislocation & 0.025 & $0.014-0.043$ \\
\hline Overall & 0.012 & $0.006-0.025$ \\
\hline \multicolumn{3}{|l|}{ Intra-prosthetic dislocation } \\
\hline Primary THA & 0.008 & $0.006-0.010$ \\
\hline Revision THA & 0.010 & $0.007-0.015$ \\
\hline Recurrent dislocation & 0.016 & $0.008-0.031$ \\
\hline Overall & 0.010 & $0.007-0.015$ \\
\hline \multicolumn{3}{|l|}{ Periprosthetic fracture } \\
\hline Primary THA & 0.009 & $0.007-0.011$ \\
\hline Revision THA & 0.009 & $0.006-0.012$ \\
\hline Recurrent dislocation & 0.013 & $0.006-0.025$ \\
\hline Overall & 0.009 & $0.008-0.011$ \\
\hline \multicolumn{3}{|l|}{ Implant failure } \\
\hline Primary THA & 0.023 & $0.018-0.030$ \\
\hline Revision THA & 0.055 & $0.042-0.073$ \\
\hline Recurrent dislocation & 0.060 & $0.034-0.103$ \\
\hline Overall & 0.042 & $0.021-0.081$ \\
\hline \multicolumn{3}{|l|}{ Harris Hip score } \\
\hline Primary THA & 89.47 & $87.62-91.33$ \\
\hline Revision THA & 81.89 & $78.96-84.83$ \\
\hline Recurrent dislocation & 82.65 & $77.41-87.89$ \\
\hline Overall & 84.87 & 78.99-90.76 \\
\hline \multicolumn{3}{|l|}{ Merle d'Aubigné score } \\
\hline Primary THA & 17.08 & $16.85-17.30$ \\
\hline Revision THA & 15.45 & $15.07-15.83$ \\
\hline Recurrent dislocation & 16.57 & $15.85-17.28$ \\
\hline Overall & 16.36 & $15.20-17.53$ \\
\hline
\end{tabular}

and for recurrent dislocation $(\beta=1.08,95 \%$ CI 0.24 1.92) were risk factors for implant failures (Table 5).

\section{Functional outcome}

We included $49(\mathrm{~N}=7086)$ and $21(\mathrm{~N}=2764)$ studies that evaluated the functional outcome using Harris hip score and Merle d'Aubigné score. The pooled Harris hip score and Merle d'Aubigné score were 84.87 (95\% CI 78.99 - 90.76) and 16.36 (95\% CI 15.20 - 17.53), respectively (Table 4, Figure S7, S8). Revision THA procedure for all causes $(\beta=-9.44,95 \%$ CI $-15.17--3.72)$ and female sex $(\beta=-4.10,95 \%$ CI $-8.17--0.03)$ were associated with lower functional scores. (Table 5).

\section{Discussion}

In this meta-analysis, we included 119 studies with 30016 primary and revision THA procedures using the modern DM design. At a mean follow-up of 47.3 months, the overall failure rate of modern dual mobility design was $4.2 \%$. The most common failure modes include aseptic loosening (primary: $0.9 \%$, revision for all causes: $2.2 \%$, revision for recurrent dislocation: $2.4 \%$, septic loosening (primary: $0.8 \%$, revision for all causes: $2.3 \%$, revision for recurrent dislocation: $2.5 \%$ ), extraarticular dislocation (primary: $0.6 \%$, revision for all causes: $1.3 \%$, revision for recurrent dislocation: $2.5 \%$ ), intra-prosthetic dislocation (primary: $0.8 \%$, revision for all causes: $1.0 \%$, revision for recurrent dislocation: $1.6 \%$ ) and periprosthetic fracture (primary: $0.9 \%$, revision for all causes: $0.9 \%$, revision for recurrent dislocation: $1.3 \%)$. The multi-regression analysis revealed that revision THA procedures were associated with a higher risk of aseptic loosening, septic loosening, extra-articular dislocation, periprosthetic fracture, overall implant failure and lower Harris Hip scores. Interestingly, several risk factors that were identified for THA dislocation such as advanced age, female sex, posterolateral approach and increased BMI were not risk factors for extra-articular dislocation. On the other hand, younger and female patients were associated with higher risk of implant failure. In terms of functional outcome, the patients were satisfied with their postoperative function based on the improved Harris hip score and Merle d'Aubigné score.

Dislocation is one of the common causes of THA implant failure and can be caused by many factors [8]. In current literature, the known risk factors include advanced age, female patients $[9,10]$, obesity $[11,12]$, previous hip surgeries [13], posterolateral surgical approach $[14,15]$, THA for acute fractures, patients with neurological diseases [16], and patients with abductor weakness $[17,18]$. The dual mobility design increases femoral head-to-neck ratio and jump distance to improve stability [20-23]. Therefore, we can anticipate decreased dislocation rates for the DM design in primary and revision 
Table 5 Multivariate linear regression analysis

\begin{tabular}{|c|c|c|c|}
\hline Independent Variable & $\beta$-Coefficient & 95\% Confidence Interval & P Value \\
\hline \multicolumn{4}{|l|}{ Aseptic loosening } \\
\hline Age & -0.02 & $-0.05-0.01$ & 0.269 \\
\hline Female Sex & 0.55 & $-2.08-3.17$ & 0.683 \\
\hline Posterolateral approach (ref to others) & 0.18 & $-0.59-0.94$ & 0.654 \\
\hline BMI & -0.07 & $-0.19-0.06$ & 0.302 \\
\hline \multicolumn{4}{|l|}{ Indication (ref to primary THA) } \\
\hline Revision THA & 1.30 & $0.71-1.89$ & $<0.001$ \\
\hline Recurrent dislocation & 1.18 & $0.26-2.10$ & 0.012 \\
\hline \multicolumn{4}{|l|}{ Septic loosening } \\
\hline Age & -0.02 & $-0.05-0.01$ & 0.226 \\
\hline Female Sex & 1.39 & $-1.54-4.32$ & 0.353 \\
\hline Posterolateral approach (ref to others) & 0.34 & $-0.42-1.10$ & 0.384 \\
\hline BMI & -0.09 & $-0.20-0.02$ & 0.125 \\
\hline \multicolumn{4}{|l|}{ Indication (ref to primary THA) } \\
\hline Revision THA & 1.85 & $1.26-2.44$ & $<0.001$ \\
\hline Recurrent dislocation & 1.40 & $0.45-2.36$ & 0.004 \\
\hline \multicolumn{4}{|l|}{ Extra-articular dislocation } \\
\hline Age & 0.01 & $-0.03-0.05$ & 0.741 \\
\hline Female Sex & 1.18 & $-1.82-4.18$ & 0.440 \\
\hline Posterolateral approach (ref to others) & -0.39 & $-1.20-0.41$ & 0.338 \\
\hline BMI & -0.10 & $-0.24-0.03$ & 0.126 \\
\hline \multicolumn{4}{|l|}{ Indication (ref to primary THA) } \\
\hline Revision THA & 1.02 & $0.30-1.73$ & 0.006 \\
\hline Recurrent dislocation & 0.78 & $-0.49-2.04$ & 0.230 \\
\hline \multicolumn{4}{|l|}{ Intra-prosthetic dislocation } \\
\hline Age & 0.00 & $-0.05-0.04$ & 0.829 \\
\hline Female Sex & 1.30 & $-2.04-4.64$ & 0.444 \\
\hline Posterolateral approach (ref to others) & -0.31 & $-1.19-0.56$ & 0.482 \\
\hline BMI & -0.05 & $-0.18-0.08$ & 0.473 \\
\hline \multicolumn{4}{|l|}{ Indication (ref to primary THA) } \\
\hline Revision THA & 0.52 & $-0.24-1.28$ & 0.180 \\
\hline Recurrent dislocation & 0.88 & $-0.19-1.94$ & 0.107 \\
\hline \multicolumn{4}{|l|}{ Periprosthetic fracture } \\
\hline Age & -0.02 & $-0.06-0.02$ & 0.340 \\
\hline Female Sex & 0.81 & $-2.47-4.08$ & 0.629 \\
\hline Posterolateral approach (ref to others) & 0.21 & $-0.70-1.12$ & 0.651 \\
\hline BMl & -0.07 & $-0.22-0.08$ & 0.364 \\
\hline \multicolumn{4}{|l|}{ Indication (ref to primary THA) } \\
\hline Revision THA & 0.93 & $0.23-1.62$ & 0.009 \\
\hline Recurrent dislocation & 0.42 & $-0.93-1.77$ & 0.542 \\
\hline \multicolumn{4}{|l|}{ Implant failure } \\
\hline Age & -0.04 & $-0.07--0.02$ & 0.002 \\
\hline Female Sex & 3.34 & $0.91-5.78$ & 0.007 \\
\hline Posterolateral approach (ref to others) & 0.34 & $-0.32-1.01$ & 0.309 \\
\hline
\end{tabular}


Table 5 Multivariate linear regression analysis (Continued)

\begin{tabular}{|c|c|c|c|}
\hline Independent Variable & $\beta$-Coefficient & 95\% Confidence Interval & P Value \\
\hline BMI & -0.06 & $-0.16-0.05$ & 0.273 \\
\hline \multicolumn{4}{|l|}{ Indication (ref to primary THA) } \\
\hline Revision THA & 1.48 & $0.93-2.03$ & $<0.001$ \\
\hline Recurrent dislocation & 1.08 & $0.24-1.92$ & 0.012 \\
\hline \multicolumn{4}{|l|}{ Harris Hip score } \\
\hline Age & -0.01 & $-0.34-0.32$ & 0.964 \\
\hline Female Sex & 3.66 & $-15.82-23.15$ & 0.713 \\
\hline Posterolateral approach (ref to others) & -1.71 & $-8.11-4.69$ & 0.601 \\
\hline BMI & 0.58 & $-0.48-1.64$ & 0.285 \\
\hline \multicolumn{4}{|l|}{ Indication (ref to primary THA) } \\
\hline Revision THA & -9.44 & $-15.17--3.72$ & 0.001 \\
\hline Recurrent dislocation & -6.81 & $-15.42-1.80$ & 0.121 \\
\hline \multicolumn{4}{|l|}{ Merle d'Aubigné score } \\
\hline Age & 0.03 & $-0.03-0.09$ & 0.378 \\
\hline Female Sex & -4.10 & $-8.17--0.03$ & 0.049 \\
\hline Posterolateral approach (ref to others) & 0.23 & $-0.64-1.11$ & 0.600 \\
\hline BMl & 0.14 & $-0.03-0.31$ & 0.109 \\
\hline \multicolumn{4}{|l|}{ Indication (ref to primary THA) } \\
\hline Revision THA & -0.38 & $-1.45-0.69$ & 0.487 \\
\hline Recurrent dislocation & -0.37 & $-1.81-1.07$ & 0.617 \\
\hline
\end{tabular}

BMI: body mass index; ref: reference; THA: total hip arthroplasty

THA. Even after revision THA due to recurrent instability, the dislocation rate was only $2.5 \%$, which was much lower than the reported dislocation rate after primary THAs and revision THAs, which ranged from $0.3 \%$ to $10 \%$ [2-4] and $5 \%$ to $30 \%$ [5-7], respectively. In addition, a multivariate analysis revealed that older age, female patients, posterolateral approach and BMI were not risk factors for dislocation after DM-THA. Based on the difference in risk factors for dislocations, we can assume that the DM design can effectively overcome some of the shortcomings of previous THA designs. Nevertheless, optimization of component position and restoration of soft tissue tension are paramount to prevent dislocation in both primary and revision THA procedures.

Despite these improvements, there are still some concerns with the DM design, including increased wear of the acetabular liner [164], increased risk of aseptic loosening [30] and intra-prosthetic dislocation [30].

The two-articulation design creates two surfaces for plastic deformation and wear, which theoretically leads to a higher wear rate than fixed-bearing THA. The inner, small articulation dominates the majority of movement and follows the Charnley's low-friction principle with a small-diameter head to reduce wear [20]. The motion between the outer shell and acetabular component occurs in extreme angle when femoral neck abuts the PE liner and creates a homogenous wear over the liner [40]. Using plain radiographs or implant retrieval analysis, several studies aimed to assess the volumetric difference in wearing of DM articulations and fixed-bearing THA [165-172]. Interestingly, the wear rate of ultra-high molecular weight polyethylene (UHMWPE) bearing in the $1^{\text {st }}$ generation DM cup was less than $40 \mathrm{~mm}^{3}$ /year, which was similar to wear rate of UHMWPE in fixed-bearing THAs $\left(30-80 \mathrm{~mm}^{3} /\right.$ year at 15 to 21 year follow up) [165-169]. In vitro simulation study for modern generation DM cup, using highly cross-linked polyethylene (HXLPE), reported lower wear rate in DM cup compared to fixed-bearing THA (1.2 vs. $2.7 \mathrm{~mm}^{3} /$ million cycles, respectively) [170]. In another study performed by Laende et al., the wear rate of modern generation DM cups with HXLPE at 3 years followup was $0.02 \mathrm{~mm} /$ year in DM cup, which was similar to non-dual mobility constructs ( 0.00 to $0.06 \mathrm{~mm} /$ year) [69, 171]. In contrast, Deckard et al. recorded the wear rate was two times higher for modern-generation DM cup with HXLPE than the fixed-bearing THA $(0.27 \mathrm{~mm} /$ year and $0.11 \mathrm{~mm} /$ year, respectively) [172]. The in vitro simulation or retrieval studies have validated reasonable wear rates of DM articulation using either UHMWPE or HXLPE [165-170]. The results from studies using plain radiographs to estimate the wear rate were controversial, which is considered less accurate than the retrieval or simulation studies $[171,172]$. Currently, there is limited 
evidence regarding the increased PE wear of modern DM articulation.

The non-porous alumina-coated surface, tripod anchoring system of acetabular component and polyethylene wear have been associated with a higher aseptic loosening rate in the first-generation DM implants [24, 29, 31]. Several changes have been made in modern dual mobility designs, including [1] to replace UHMWPE with HXLPE to reduce wear [33, 34]; (2) to add bevelled edges (or chamfer) in polyethylene (PE) inserts to lower femoral neck impingement and wear [32]; (3) press-fit fixation by bilayer coating of porous titanium and hydroxyapatite to enhance osseointegration on the outer surface [31]; (4) modular metal liner design to facilitate supplementary screw fixation. The long-term overall survival and aseptic loosening rate of the primary THAs using $1^{\text {st }}$ generation DM implants were $85-95.4 \%$ and 3$8.3 \%$, respectively [24-28]. In this study, the primary THAs using modern generations DM implants are associated with a better overall survival (97.7\%) and a lower aseptic loosening rate $(0.9 \%)$. This pooled aseptic loosening rate was comparable to that of primary, fixedbearing THA from several registries, which ranged from $0.7-1.1 \%$ at 5 to 16 years $[1,173,174]$.

The modern, modular design has an additional cobaltchromium $(\mathrm{CoCr})$ liner inserted into a titanium acetabular component allowing supplementary screw fixation to enhance primary stability. However, the metal-on-metal interface between $\mathrm{CoCr}$ liner and titanium cup is at risk of fretting corrosion and remains a concern [175-177]. Metal ions can further lead to advance local tissue reaction (ALRT) and implant loosening [178]. The first study regarding metal ions was conducted by Matsen Ko et al., which revealed $21 \%$ of the patient had elevated serum chromium levels [179]. Other studies reported that serum ion levels (cobalt, chromium or titanium) was elevated in $9.3-23 \%$ of the patients [47, 111]. On the other hand, some studies have noted that this elevation was not associated with clinical adverse events including instability, loosening or need of revision [64, 67, 72]. In summary, the current evidence suggests there is a slight elevation of serum ion level but this does not negatively affect the implant survival.

Intra-prosthetic dislocation (IPD) is a rare complication of DM design, which occurs as a result of retentive failure of the inner articulation. Long-term, homogenous PE wear or impingement at extreme range of motion between neck and PE liner leads to loss of PE retentive rim and IPD [180, 181]. The incidence of IPD ranged from $0.7 \%-4.3 \%$ in first generation of DM cup and $[29,30]$ modifications have been made to the $2^{\text {nd }}$ generation DM implants. These changes include a thinner, more polished femoral neck to reduce impingement with the liner and the use of HXLPE to reduce wear during contact [32]. In this study, we noted a lower IPD rate with the modern design in primary THA and revision THA was $0.8 \%$ and $1.0 \%$ respectively, which is much lower than the $1^{\text {st }}$ generation $[29,30]$. Another form of IPD has been observed in modern generation DM implants, which often occurs in the short-term. This form of IPD results from a secondary decapsulation of the liner followed by reduction for dislocation [182]. During close reduction of a dislocated DM-THA, impingement occurs between the PE liner and the posterior edge of the acetabular component. The excessive loading during reduction maneuver may "decapsulate" the femoral head from PE liner. Therefore, the reduction should be performed gradually under general anesthesia to reduce excessive muscle tension [29].

Our meta-analysis showed that the mid-term revision rates in primary and revision DM-THA were 2.3\% and 5.5-6.0\%, respectively. These results were comparable to the reported outcome of primary or revision, fixedbearing THA $[1,38,39,60,73,98,108,183,184]$. In primary fixed-bearing THA, the mid-term and long-term revision rate ranged from $1.2-4.0 \%$ and $12.1-14.3 \%$, respectively $[1,38,60,73,98,108,183]$. In revision fixedbearing THA, the mid-term and long-term revision rates can be up to $5.3-13 \%$ and $27-45 \%$, respectively $[39,184]$.

This meta-analysis revealed promising mid-term outcomes and a reduction in dislocation rate, but the longterm implant survival of modern DM-THA is still lacking. For revision THA procedures, younger age and female patients were associated with a higher risk of implant failure. Younger patients have been established as a risk factor for failure after primary THAs. However, whether female sex is a risk factor remains controversial [185-188]. This can be attributed to the representativeness of the study cohort, follow-up duration and type of implant. Although female patients have been associated with increased risk of dislocation, aseptic loosening, periprosthetic fracture and overall implant failure after primary THA $[187,188]$, the same was not seen in DMTHA aside from overall implant failure. Potential confounders and inadequate follow-up duration are important considerations when interpreting this result.

We should recognize several limitations. First, we only included studies which the full text was available in English. In addition, due to the nature of our research question, the level of evidence of the included studies was low (III or IV). Second, we included studies that reported outcome of modern DM (the $2^{\text {nd }}$ and $3^{\text {rd }}$ generation) implants over a time span of 12 years between 2008 to 2020. Modern DMTHA implants were developed in the 1990s, and the studies about modern DM-THA implants were mostly conducted after 2000. We could only analyze factors that were clearly described in the studies, including 
age, sex, surgical approach, BMI and indication for hip arthroplasty. Factors such as surgeons' experience, patient activity level or implant designs could have affected the outcome but were unavailable and thus were not analyzed. Therefore, we considered articles that were conducted after 2000. Third, the protocol of this meta-analysis has not been registered, which can have a risk for reporting bias. Fourth, we did not include grey literature or unpublished studies in this work. Nonetheless, this review provides an updated review regarding the outcome of modern DM implants and factors that might affect the outcome.

\section{Conclusions}

In conclusion, the mid-term implant survival of modern dual-mobility design was satisfactory. Aseptic loosening continues to be the most common failure mode after DM-THA. Younger age and female sex were correlated with implant failure.

\section{Abbreviations}

DM: Dual mobility; THA: total hip arthroplasty; BMl: body mass index; IPD: intra-prosthetic dislocation; PRISMA: Preferred Reporting Items for Systematic Reviews and Meta-analysis; Cl: confidence interval;

CMA: Comprehensive Meta-Analysis; UHMWPE: ultra-high molecular weight polyethylene; HXLPE: highly cross-linked polyethylene; PE: polyethylene; CoCr: cobalt-chromium; ALRT: advance local tissue reaction

\section{Supplementary Information}

The online version contains supplementary material available at https://doi. org/10.1186/s12891-021-04404-4.

Additional file 1:Figure S1. Forest plot of the pooled aseptic loosening rate among included studies.

Additional file 2: Figure S2. Forest plot of the pooled septic loosening rate among included studies.

Additional file 3: Figure S3. Forest plot of the pooled extra-articular dislocation rate among included studies.

Additional file 4: Figure S4. Forest plot of the pooled intra-prosthetic dislocation rate among included studies.

Additional file 5: Figure S5. Forest plot of the pooled periprosthetic fracture rate among included studies.

Additional file 6: Figure S6. Forest plot of the pooled implant failure rate among included studies.

Additional file 7: Figure S7. Forest plot of the pooled Harris hip score among included studies.

Additional file 8: Figure S8. Forest plot of the pooled Merle d'Aubigné score among included studies.

\section{Acknowledgements}

Not applicable

\section{Authors' contributions}

FYP and SWT were responsible for conception and design, publication screening, acquisition of data, analysis and interpretation, and drafting and revising the manuscript. HHM and TFAC were initial analysis and prepared tables. TWH and KCH prepared figures. CFC and WMC were responsible for reviewing and revising the manuscript. All authors were involved with interpretation of the data. All authors discussed the results and commented on the manuscript. The author(s) read and approved the final manuscript.

\section{Funding}

This work was financially supported by Mr. Morris Chang and Ms. Sophie Chang. The funding sources had no involvement and conflict of interests in this study.

\section{Availability of data and materials}

As this is a review and meta-analysis, we completed a comprehensive search on PubMed, MEDLINE, Cochrane Reviews and Embase for studies. All data generated or analysed during this study are included in this published article [and its supplementary information files]

\section{Declarations}

Ethics approval and consent to participate

Not applicable

\section{Consent for publication}

Not applicable

\section{Competing interests}

The authors declare that they have no competing interests

\section{Author details}

${ }^{1}$ Department of Orthopaedics and Traumatology, Taipei Veterans General Hospital, No. 201, Sec 2, Shi-Pai Road, Taipei 112, Taiwan. ${ }^{2}$ Department of Orthopaedics, School of Medicine, National Yang-Ming Chiao-Tung University, Taipei, Taiwan. ${ }^{3}$ Chang Gung University College of Medicine, Taoyuan, Taiwan. ${ }^{4}$ Department of Orthopaedic Surgery, Chang-Gung Memorial Hospital, Chiayi, Taiwan.

Received: 16 November 2020 Accepted: 24 May 2021

Published online: 14 June 2021

\section{References}

1. American Joint Replacement Registry. 2019 Sixth AJRR Annual Report on Hip and Knee Arthroplasty Data. 2019; http://connect.ajrr.net/2019-ajrr-a nnual-report. Accessed 13 Sept 2020.

2. Bozic KJ, Kurtz SM, Lau E, Ong K, Vail TP, Berry DJ. The epidemiology of revision total hip arthroplasty in the United States. J Bone Joint Surg Am. 2009;91(1):128-33.

3. Berry DJ, von Knoch M, Schleck CD, Harmsen WS. Effect of femoral head diameter and operative approach on risk of dislocation after primary total hip arthroplasty. J Bone Joint Surg Am. 2005;87(11):2456-63.

4. Parvizi J, Picinic E, Sharkey PF. Revision total hip arthroplasty for instability: surgical techniques and principles. J Bone Joint Surg Am. 2008;90(5):113442.

5. Berend KR, Sporer SM, Sierra RJ, Glassman AH, Morris MJ. Achieving stability and lower-limb length in total hip arthroplasty. J Bone Joint Surg Am. 2010; 92(16):2737-52.

6. Parvizi J, Picinic E, Sharkey PF. Revision total hip arthroplasty for instability: surgical techniques and principles. Instr Course Lect. 2009;58:183-91.

7. Wetters NG, Murray TG, Moric M, Sporer SM, Paprosky WG, Della Valle CJ. Risk factors for dislocation after revision total hip arthroplasty. Clinical Orthopaedics and Related Research. 2013;471(2):410-6.

8. Delaunay C, Hamadouche M, Girard J, Duhamel A, So FG. What are the causes for failures of primary hip arthroplasties in France? Clinical Orthopaedics and RELATED Research. 2013;471(12):3863-9.

9. Newington DP, Bannister GC, Fordyce M. Primary total hip replacement in patients over 80 years of age. The Journal of Bone and Joint Surgery British. 1990;72(3):450-2.

10. Woolson ST, Rahimtoola ZO. Risk factors for dislocation during the first 3 months after primary total hip replacement. J Arthroplasty. 1999;14(6):662-8.

11. Davis AM, Wood AM, Keenan AC, Brenkel IJ, Ballantyne JA. Does body mass index affect clinical outcome post-operatively and at five years after primary unilateral total hip replacement performed for osteoarthritis? A multivariate analysis of prospective data. The Journal of Bone and Joint Surgery British. 2011;93(9):1178-82.

12. Kim Y, Morshed S, Joseph T, Bozic K, Ries MD. Clinical impact of obesity on stability following revision total hip arthroplasty. Clinical Orthopaedics and Related Research. 2006;453:142-6. 
13. Padgett $D E$, Warashina $H$. The unstable total hip replacement. Clinical Orthopaedics and Related Research. 2004;420:72-9.

14. Patel PD, Potts A, Froimson MI. The dislocating hip arthroplasty: prevention and treatment. J Arthroplasty. 2007;22(4 Suppl 1):86-90.

15. Miller LE, Gondusky JS, Kamath AF, Boettner F, Wright J, Bhattacharyya S. Influence of surgical approach on complication risk in primary total hip arthroplasty. Acta Orthop. 2018;89(3):289-94.

16. Raphael BS, Dines JS, Akerman M, Root L. Long-term followup of total hip arthroplasty in patients with cerebral palsy. Clinical Orthopaedics and Related Research. 2010;468(7):1845-54.

17. Schroeder K, Hauck C, Wiedenhofer B, Braatz F, Aldinger PR. Long-term results of hip arthroplasty in ambulatory patients with cerebral palsy. International Orthopaedics. 2010;34(3):335-9.

18. Bourne RB, Mehin R. The dislocating hip: what to do, what to do. J Arthroplasty. 2004;19(4 Suppl 1):111-4.

19. Bousquet G, Argenson C, Godeneche JL, Cisterne JP, Gazielly DF, Girardin P, et al. Recovery after aseptic loosening of cemented total hip arthroplasties with Bousquet's cementless prosthesis. Apropos of 136 cases. Rev Chir Orthop Reparatrice Appar Mot. 1986;72(Suppl 2):70-4.

20. Charnley J. The long-term results of low-friction arthroplasty of the hip performed as a primary intervention. The Journal of Bone and Joint Surgery British. 1972;54(1):61-76.

21. McKee GK, Watson-Farrar J. Replacement of arthritic hips by the McKeeFarrar prosthesis. The Journal of Bone and Joint Surgery British. 1966;48(2): 245-59.

22. Howie DW, Holubowycz OT, Middleton R. Large Articulation Study G. Large femoral heads decrease the incidence of dislocation after total hip arthroplasty: a randomized controlled trial. The Journal of Bone and Joint Surgery American. 2012;94(12):1095-102.

23. Cooper HJ, Della Valle CJ. Large diameter femoral heads: is bigger always better? Bone Joint J. 2014;96-B(11 Supple A):23-6.

24. Farizon F, de Lavison R, Azoulai JJ, Bousquet $\mathrm{G}$. Results with a cementless alumina-coated cup with dual mobility. A twelve-year follow-up study. International Orthopaedics. 1998:22(4):219-24.

25. Philippot R, Farizon F, Camilleri JP, Boyer B, Derhi G, Bonnan J, et al. Survival of cementless dual mobility socket with a mean 17 years follow-up. Rev Chir Orthop Reparatrice Appar Mot. 2008;94(8):e23-7.

26. Boyer B, Philippot R, Geringer J, Farizon F. Primary total hip arthroplasty with dual mobility socket to prevent dislocation: a 22-year follow-up of 240 hips. International Orthopaedics. 2012;36(3):511-8.

27. Aubriot JH, Lesimple P, Leclercq S. Study of Bousquet's non-cemented acetabular implant in 100 hybrid total hip prostheses (Charnley type cemented femoral component). Average 5-year follow-up. Acta Orthop Belg. 1993;59(Suppl 1):267-71.

28. Vielpeau C, Lebel B, Ardouin L, Burdin G, Lautridou C. The dual mobility socket concept: experience with 668 cases. International Orthopaedics. 2011;35(2):225-30.

29. Neri T, Philippot R, Klasan A, Putnis S, Leie M, Boyer B, et al. Dual mobility acetabular cups for total hip arthroplasty: advantages and drawbacks. Expert Rev Med Devices. 2018;15(11):835-45.

30. Philippot R, Boyer B, Farizon F. Intraprosthetic dislocation: a specific complication of the dual-mobility system. Clinical Orthopaedics and Related Research. 2013;471(3):965-70.

31. Massin P, Orain V, Philippot R, Farizon F, Fessy MH. Fixation failures of dual mobility cups: a mid-term study of 2601 hip replacements. Clinical Orthopaedics and Related Research. 2012;470(7):1932-40.

32. Aslanian T. All dual mobility cups are not the same. International Orthopaedics. 2017:41(3):573-81.

33. Callary SA, Field JR, Campbell DG. Low wear of a second-generation highly crosslinked polyethylene liner: a 5-year radiostereometric analysis study. Clinical Orthopaedics and Related Research. 2013;471(11):3596-600.

34. Campbell DG, Field JR, Callary SA. Second-generation highly cross-linked X3 polyethylene wear: a preliminary radiostereometric analysis study. Clinical Orthopaedics and Related Research. 2010:468(10):2704-9.

35. You D, Sepehri A, Kooner S, Krzyzaniak H, Johal H, Duffy P, et al. Outcomes of total hip arthroplasty using dual mobility components in patients with a femoral neck fracture. Bone Joint J. 2020;102-B(7):811-21.

36. Romagnoli M, Grassi A, Costa GG, Lazaro LE, Lo Presti M, Zaffagnini S. The efficacy of dual-mobility cup in preventing dislocation after total hip arthroplasty: a systematic review and meta-analysis of comparative studies. International Orthopaedics. 2019;43(5):1071-82.
37. Reina N, Pareek A, Krych AJ, Pagnano MW, Berry DJ, Abdel MP. Dualmobility constructs in primary and revision total hip arthroplasty: a systematic review of comparative studies. J Arthroplasty. 2019;34(3):594-603.

38. Jonker RC, van Beers L, van der Wal BCH, Vogely HC, Parratte S, Castelein RM, et al. Can dual mobility cups prevent dislocation without increasing revision rates in primary total hip arthroplasty? A systematic review. Orthopaedics \& Traumatology, Surgery \& Research : OTSR. 2020;106(3):50917.

39. Levin JM, Sultan AA, O'Donnell JA, Sodhi N, Khlopas A, Piuzzi NS, et al. Modern dual-mobility cups in revision total hip arthroplasty: a systematic review and meta-analysis. J Arthroplasty. 2018;33(12):3793-800.

40. Darrith B, Courtney PM, Della Valle CJ. Outcomes of dual mobility components in total hip arthroplasty: a systematic review of the literature. Bone Joint J. 2018;100-B(1):11-9.

41. Klemt C, Smith EJ, Oganesyan R, Limmahakhun S, Fitz D, Kwon YM. Outcome of dual mobility constructs for adverse local tissue reaction associated abductor deficiency in revision total hip arthroplasty. J Arthroplasty. 2020

42. Dubin J, Huang RC, Muskat A, Sharpe K, Malkani AL, Mont M, et al. Five-year follow-up of clinical outcomes with an anatomic dual-mobility acetabular system: a multicenter study. Arthroplast Today. 2020;6(3):543-7.

43. Ait MM. Postero-posterolateral approach in total hip arthroplasty. International Orthopaedics. 2020.

44. Abdel MP, Miller LE, Hull SA, Coppolecchia AB, Hanssen AD, Pagnano MW. Cost analysis of dual-mobility constructs in revision total hip arthroplasty: a European payer perspective. Orthopedics. 2020;43(4):250-5.

45. Schmidt A, Batailler C, Fary C, Servien E, Lustig S. Dual mobility cups in revision total hip arthroplasty: efficient strategy to decrease dislocation risk. J Arthroplasty. 2020;35(2):500-7.

46. de l'Escalopier N, Dumaine V, Auberger G, Babinet A, Courpied JP, Anract P, et al. Dual mobility constructs in revision total hip arthroplasty: survivorship analysis in recurrent dislocation versus other indications at three to twelveyear follow-up. International Orthopaedics. 2020;44(2):253-60.

47. Civinini R, Cozzi Lepri A, Carulli C, Matassi F, Villano M, Innocenti M. Patients following revision total hip arthroplasty with modular dual mobility components and cobalt-chromium inner metal head are at risk of increased serum metal ion levels. J Arthroplasty. 2020;35(6S):S294-S8.

48. Favreau $\mathrm{H}$, Ehlinger $\mathrm{M}$, Adam $\mathrm{P}$, Bonnomet $\mathrm{F}$. Total hip arthroplasty with exclusive use of dual-mobility cup after failure of internal fixation in trochanteric fracture. Orthopaedics \& Traumatology, Surgery \& Research : OTSR. 2020;106(4):645-9.

49. Rashed RAM, Sevenoaks H, Choudry QA, Kasem MS, Elkhadrawe TA, Eldakhakhny MM. Comparison of functional outcome of cemented total hip replacement versus cemented dual-mobility cup total hip replacement for the management of displaced femoral neck fractures in the active elderly patients. Hip Int. 2020;1120700020910414.

50. Nessler JM, Malkani AL, Sachdeva S, Nessler JP, Westrich G, Harwin SF, et al. Use of dual mobility cups in patients undergoing primary total hip arthroplasty with prior lumbar spine fusion. International Orthopaedics. 2020;44(5):857-62

51. Dubin JA, Westrich GH. Lack of early dislocation for dual mobility vs. fixed bearing total hip arthroplasty: A multi-center analysis of comparable cohorts. J Orthop. 2020:21:1-5.

52. Tabori-Jensen S, Mosegaard SB, Hansen TB, Stilling M. Inferior stabilization of cementless compared with cemented dual-mobility cups in elderly osteoarthrosis patients: a randomized controlled radiostereometry study on 60 patients with 2 years' follow-up. Acta Orthop. 2020;91(3):246-53.

53. Hoggett $L$, Cross $C$, Helm A. Acetabular revision using a dual mobility cup as treatment for dislocation in Charnley total hip arthroplasty. Bone Joint J. 2020;102-B(4):423-5.

54. Li WT, Kozick Z, Sherman M, Restrepo C, Smith EB, Courtney PM. Dual mobility bearing articulations result in lower rates of dislocation after revision total hip arthroplasty. The Journal of the American Academy of Orthopaedic Surgeons. 2019

55. Jones CW, De Martino I, D'Apolito R, Nocon AA, Sculco PK, Sculco TP. The use of dual-mobility bearings in patients at high risk of dislocation. Bone Joint J. 2019;101-B(1_Supple_A):41-5.

56. Huang RC, Malkani AL, Harwin SF, Hozack WJ, Mont MA, Higuera-Rueda CA, et al. Multicenter evaluation of a modular dual mobility construct for revision total hip arthroplasty. J Arthroplasty. 2019;34(7S):S287-S91. 
57. Dikmen G, Ozden VE, Karaytug K, Tozun R. Dual-mobility cups in revision acetabular reconstructions: Short-term outcomes in high-risk patients for instability. Acta Orthop Traumatol Turc. 2019;53(5):329-33.

58. Cypres A, Fiquet A, Girardin P, Fitch D, Bauchu P, Bonnard O, et al. Longterm outcomes of a dual-mobility cup and cementless triple-taper femora stem combination in total hip replacement: a multicenter retrospective analysis. J Orthop Surg Res. 2019;14(1):376.

59. Boulat S, Neri T, Boyer B, Philippot R, Farizon F. Dual mobility cups in total hip arthroplasty after failed internal fixation of proximal femoral fractures. Orthopaedics \& Traumatology, Surgery \& Research : OTSR. 2019;105(3):491-5.

60. Bloemheuvel EM, van Steenbergen LN, Swierstra BA. Dual mobility cups in primary total hip arthroplasties: trend over time in use, patient characteristics, and mid-term revision in 3,038 cases in the Dutch Arthroplasty Register (2007-2016). Acta Orthop. 2019;90(1):11-4.

61. Bloemheuvel EM, Steenbergen LNV, Swierstra BA. Lower 5-year cup rerevision rate for dual mobility cups compared with unipolar cups: report of 15,922 cup revision cases in the Dutch Arthroplasty Register (2007-2016). Acta Orthop. 2019:90(4):338-41.

62. Assi C, Barakat H, Mansour J, Samaha C, Yammine K. Primary total hip arthroplasty: mid-term outcomes of dual-mobility cups in patients at high risk of dislocation. Hip Int. 2019;1120700019889031.

63. Addona JL, Gu A, De Martino I, Malahias MA, Sculco TP, Sculco PK. High rate of early intraprosthetic dislocations of dual mobility implants: a single surgeon series of primary and revision total hip replacements. J Arthroplasty. 2019;34(11):2793-8.

64. Chalmers BP, Mangold DG, Hanssen AD, Pagnano MW, Trousdale RT, Abdel MP. Uniformly low serum cobalt levels after modular dual-mobility total hip arthroplasties with ceramic heads: a prospective study in high-risk patients. Bone Joint J. 2019;101-B(6_Supple_B):57-61.

65. Dubin JA, Westrich GH. Anatomic dual mobility compared to modular dual mobility in primary total hip arthroplasty: a matched cohort study. Arthroplast Today. 2019;5(4):509-14.

66. Schmidt-Braekling T, Sieber D, Gosheger G, Theil JC, Moellenbeck B, Andreou D, et al. Dislocation rates with combinations of anti-protrusio cages and dual mobility cups in revision cases: Are we safe? PloS one. 2019; 14(2):e0212072.

67. Markel DC, Bou-Akl T, Rossi MD, Pizzimenti N, Wu B, Ren W. Blood metal levels, leucocyte profiles, and cytokine profiles in patients with a modular dual-mobility hip prosthesis: early results from a prospective cohort study. Bone Joint J. 2019;101-B(9):1035-41.

68. Colacchio ND, Wooten CJ, Martin JR, Masonis JL, Fehring TK. Dual mobility for monoblock metal-on-metal revision-is it safe? J Arthroplasty. 2020;35(2): 508-12.

69. Laende EK, Richardson CG, Dunbar MJ. Migration and wear of a dual mobility acetabular construct at 3 years measured by radiostereometric analysis. J Arthroplasty. 2020;35(4):1109-16.

70. Ukaj S, Zhuri O, Ukaj F, Podvorica V, Grezda K, Caton J, et al. Dual mobility acetabular cup versus hemiarthroplasty in treatment of displaced femoral neck fractures in elderly patients: comparative study and results at minimum 3-year follow-up. Geriatr Orthop Surg Rehabil. 2019;10: 2151459319848610.

71. Nonne D, Sanna F, Bardelli A, Milano P, Rivera F. Use of a dual mobility cup to prevent hip early arthroplasty dislocation in patients at high falls risk. Injury. 2019;50(Suppl 4):S26-S9.

72. Nam D, Salih R, Nahhas CR, Barrack RL, Nunley RM. Is a modular dual mobility acetabulum a viable option for the young, active total hip arthroplasty patient? Bone Joint J. 2019;101-b(4):365-71.

73. Kreipke R, Rogmark C, Pedersen AB, Karrholm J, Hallan G, Havelin LI, et al. Dual mobility cups: effect on risk of revision of primary total hip arthroplasty due to osteoarthritis: a matched population-based study using the nordic arthroplasty register association database. The Journal of Bone and Joint Surgery American. 2019;101(2):169-76.

74. Jobory A, Karrholm J, Overgaard S, Becic Pedersen A, Hallan G, Gjertsen JE, et al. Reduced revision risk for dual-mobility cup in total hip replacement due to hip fracture: a matched-pair analysis of 9,040 cases from the Nordic Arthroplasty Register Association (NARA). The Journal of Bone and Joint Surgery American. 2019;101(14):1278-85.

75. Iorio R, lannotti F, Mazza D, Speranza A, Massafra C, Guzzini M, et al. Is dual cup mobility better than hemiarthroplasty in patients with dementia and femoral neck fracture? A randomized controlled trial. SICOT J. 2019;5:38.
76. Gaillard R, Kenney R, Delalande JL, Batailler C, Lustig S. Ten- to 16-year results of a modern cementless dual-mobility acetabular implant in primary total hip arthroplasty. J Arthroplasty. 2019;34(11):2704-10.

77. Fessy MH, Jacquot L, Rollier JC, Chouteau J, Ait-Si-Selmi T, Bothorel H, et al. Midterm clinical and radiographic outcomes of a contemporary monoblock dual-mobility cup in uncemented total hip arthroplasty. J Arthroplasty. 2019; 34(12):2983-91.

78. Fahad S, Nawaz Khan MZ, Aqueel T, Hashmi P. Comparison of bipolar hemiarthroplasty and total hip arthroplasty with dual mobility cup in the treatment of old active patients with displaced neck of femur fracture: A retrospective cohort study. Ann Med Surg (Lond). 2019;45:62-5.

79. Canton G, Moghnie A, Cleva M, Kostoris FM, Murena L. Dual mobility total hip arthroplasty in the treatment of femoral neck fractures: a retrospective evaluation at mid-term follow-up. Acta Biomed. 2019;90(1-S):98-103.

80. Assi CC, Barakat HB, Caton JH, Najjar EN, Samaha CT, Yammine KF. Mortality rate and mid-term outcomes of total hip arthroplasty using dual mobility cups for the treatment of femoral neck fractures in a middle eastern population. J Arthroplasty. 2019;34(2):333-7.

81. Harwin SF, Sultan AA, Khlopas A, Chughtai M, Sodhi N, Piuzzi NS, et al. Midterm outcomes of dual mobility acetabular cups for revision total hip arthroplasty. J Arthroplasty. 2018;33(5):1494-500.

82. Hartzler MA, Abdel MP, Sculco PK, Taunton MJ, Pagnano MW, Hanssen AD. Otto Aufranc Award: dual-mobility constructs in revision THA reduced dislocation, rerevision, and reoperation compared with large femoral heads. Clinical Orthopaedics and Related Research. 2018;476(2):293-301.

83. Diamond OJ, Konan S, Greidanus NV, Garbuz DS, Duncan CP, Masri BS. An early report of the use of a modular dual mobility articulation in revision acetabular reconstruction. J Arthroplasty. 2018;33(9):2961-6.

84. Hwang JH, Kim SM, Oh KJ, Kim Y. Dislocations after use of dual-mobility cups in cementless primary total hip arthroplasty: prospective multicentre series. International Orthopaedics. 2018;42(4):761-7.

85. Kavcic G, Mirt P, Bedencic K. Good mid-term clinical results of a cemented dual mobility cup: a single-centre experience. Hip Int. 2018;28(1):59-62.

86. Ozden VE, Dikmen G, Beksac B, Tozun R. Dual-mobility bearings for patients with abductor-trochanteric complex insufficiency. Hip Int. 2018;28(5):491-7.

87. Chalmers BP, Pallante GD, Taunton MJ, Sierra RJ, Trousdale RT. Can dislocation of a constrained liner be salvaged with dual-mobility constructs in revision THA? Clinical Orthopaedics and Related Research. 2018:476(2): 305-12.

88. Assi C, Caton J, Fawaz W, Samaha C, Yammine K. Revision total hip arthroplasty with a Kerboull plate: comparative outcomes using standard versus dual mobility cups. International Orthopaedics. 2019;43(10):2245-51.

89. Assi C, Kheir N, Samaha C, Kouyoumjian P, Yammine K. Early results of total hip arthroplasty using dual-mobility cup in patients with osteonecrosis of the femoral head. SICOT J. 2018;4:4.

90. Stucinskas J, Kalvaitis T, Smailys A, Robertsson O, Tarasevicius S. Comparison of dual mobility cup and other surgical construts used for three hundred and sixty two first time hip revisions due to recurrent dislocations: five year results from Lithuanian arthroplasty register. International Orthopaedics. 2018;42(5):1015-20.

91. Tabori-Jensen S, Hansen TB, Bovling S, Aalund P, Homilius M, Stilling M. Good function and high patient satisfaction at mean 2.8 years after dual mobility THA following femoral neck fracture: a cross-sectional study of 124 patients. Clin Interv Aging. 2018;13:615-21.

92. Tabori-Jensen $\mathrm{S}$, Hansen TB, Stilling M. Low dislocation rate of Saturne((R))/ Avantage((R)) dual-mobility THA after displaced femoral neck fracture: a cohort study of 966 hips with a minimum 1.6-year follow-up. Arch Orthop Trauma Surg. 2019;139(5):605-12.

93. Rashed RA, Sevenoaks H, Shabaan AM, Choudry QA, Hammad AS, Kasem MS, et al. Functional outcome and health related quality of life after dual mobility cup total hip replacement for displaced femoral neck fractures in middle aged Egyptian patients. Injury. 2018;49(3):667-72.

94. Lange JK, Spiro SK, Westrich GH. Utilizing dual mobility components for first-time revision total hip arthroplasty for instability. J Arthroplasty. 2018; 33(2):505-9

95. Kim YT, Yoo JH, Kim MK, Kim S, Hwang J. Dual mobility hip arthroplasty provides better outcomes compared to hemiarthroplasty for displaced femoral neck fractures: a retrospective comparative clinical study. International Orthopaedics. 2018;42(6):1241-6.

96. Marie-Hardy L, O'Laughlin P, Bonnin M, Ait Si Selmi T. Are dual mobility cups associated with increased metal ions in the blood? Clinical study of 
nickel and chromium levels with 29 months' follow-up. Orthopaedics \& Traumatology, Surgery \& Research : OTSR. 2018;104(8):1179-82.

97. Boukebous B, Boutroux P, Zahi R, Azmy C, Guillon P. Comparison of dual mobility total hip arthroplasty and bipolar arthroplasty for femoral neck fractures: A retrospective case-control study of 199 hips. Orthopaedics \& Traumatology, Surgery \& Research : OTSR. 2018;104(3):369-75.

98. Tarasevicius S, Smailys A, Grigaitis K, Robertsson O, Stucinskas J. Shortterm outcome after total hip arthroplasty using dual-mobility cup: report from Lithuanian Arthroplasty Register. International Orthopaedics. 2017:41(3):595-8.

99. Sutter EG, McClellan TR, Attarian DE, Bolognesi MP, Lachiewicz PF, Wellman SS. Outcomes of modular dual mobility acetabular components in revision total hip arthroplasty. J Arthroplasty. 2017;32(9S):S220-S4.

100. Lebeau N, Bayle M, Belhaouane R, Chelli M, Havet E, Brunschweiler B, et al. Total hip arthroplasty revision by dual-mobility acetabular cup cemented in a metal reinforcement: A 62 case series at a minimum 5 years' follow-up. Orthopaedics \& Traumatology, Surgery \& Research : OTSR. 2017;103(5):67984.

101. Henawy AT, Abdel BA. Dual mobility total hip arthroplasty in hemiplegic patients. SICOT J. 2017;3:40.

102. Chalmers BP, Perry KI, Hanssen AD, Pagnano MW, Abdel MP. Conversion of hip hemiarthroplasty to total hip arthroplasty utilizing a dual-mobility construct compared with large femoral heads. J Arthroplasty. 2017;32(10): $3071-5$

103. Ferreira A, Prudhon JL, Verdier R, Puch JM, Descamps L, Dehri G, et al. Contemporary dual-mobility cup regional and private register: methodology and results. International Orthopaedics. 2017;41(3):439-45.

104. Kasparek MF, Renner L, Faschingbauer M, Waldstein W, Rueckl K, Boettner F. Salvage of a monoblock metal-on-metal cup using a dual mobility liner: a two-year MRI follow-up study. International Orthopaedics. 2018;42(5):103541.

105. Ochi H, Baba T, Homma Y, Matsumoto M, Watari T, Ozaki Y, et al. Total hip arthroplasty via the direct anterior approach with a dual mobility cup for displaced femoral neck fracture in patients with a high risk of dislocation. SICOT J. 2017:3:56.

106. Graversen AE, Jakobsen SS, Kristensen PK, Thillemann TM. No dislocations after primary hip arthroplasty with the dual mobility cup in displaced femoral neck fracture in patients with dementia. A one-year follow-up in 20 patients. SICOT J. 2017;3:9.

107. Perrin A, Saab M, Putman S, Benad K, Drumez E, Chantelot C. The benefit of the systematic revision of the acetabular implant in favor of a dual mobility articulation during the treatment of periprosthetic fractures of the femur: a 49 cases prospective comparative study. European Journal of Orthopaedic Surgery \& Traumatology : Orthopedie Traumatologie. 2018;28(2):239-46.

108. Rowan FE, Salvatore AJ, Lange JK, Westrich GH. Dual-mobility vs fixedbearing total hip arthroplasty in patients under 55 years of age: a singleinstitution, matched-cohort analysis. J Arthroplasty. 2017:32(10):3076-81.

109. Spaans EA, Koenraadt KLM, Wagenmakers R, van den Hout J, Te Stroet MAJ, Bolder SBT. Midterm survival analysis of a cemented dual-mobility cup combined with bone impaction grafting in 102 revision hip arthroplasties. Hip Int. 2018;28(2):161-7.

110. Batailler C, Fary C, Batailler P, Servien E, Neyret P, Lustig S. Total hip arthroplasty using direct anterior approach and dual mobility cup: safe and efficient strategy against post-operative dislocation. International Orthopaedics. 2017:41(3):499-506.

111. Nam D, Salih R, Brown KM, Nunley RM, Barrack RL. Metal ion levels in young, active patients receiving a modular, dual mobility total hip arthroplasty. J Arthroplasty. 2017;32(5):1581-5.

112. Morin C, Ursu C, Delecourt C. Total hip replacement in young nonambulatory cerebral palsy patients. Orthopaedics \& Traumatology, Surgery \& Research : OTSR. 2016;102(7):845-9.

113. Epinette JA, Harwin SF, Rowan FE, Tracol P, Mont MA, Chughtai M, et al. Early experience with dual mobility acetabular systems featuring highly cross-linked polyethylene liners for primary hip arthroplasty in patients under fifty five years of age: an international multi-centre preliminary study. International Orthopaedics. 2017:41(3):543-50

114. Griffin XL, Parsons N, Achten J, Costa ML. A randomised feasibility study comparing total hip arthroplasty with and without dual mobility acetabular component in the treatment of displaced intracapsular fractures of the proximal femur : The Warwick Hip Trauma Evaluation Two : WHiTE Two. Bone Joint J. 2016;98-B(11):1431-5.
115. Carulli C, Macera A, Matassi F, Civinini R, Innocenti M. The use of a dual mobility cup in the management of recurrent dislocations of hip hemiarthroplasty. Journal of Orthopaedics and Traumatology : Official Journal of the Italian Society of Orthopaedics and Traumatology. 2016;17(2): 131-6.

116. Harris WH. Traumatic arthritis of the hip after dislocation and acetabular fractures: treatment by mold arthroplasty. An end-result study using a new method of result evaluation. The Journal of Bone and Joint Surgery American. 1969;51(4):737-55.

117. d'Aubigné RM, Postel M. The classic: functional results of hip arthroplasty with acrylic prosthesis. 1954. Clinical Orthopaedics and Related Research. 2009;467(1):7-27.

118. NIH. Quality assessment tool for case series studies. National Institutes of Health Web site. 2020;https:/www.nhlbi.nih.gov/health-topics/study-qua lity-assessment-tools Accessed 13 Sept 2020.

119. NIH. Quality assessment tool for case control studies. National Institutes of Health Web site. 2020;https://www.nhlbi.nih.gov/health-topics/study-qua lity-assessment-tools Accessed 14 April 2021.

120. Neil Wheelton A, Myatt D, Helm AT. Outcomes for cemented dual mobility cup to treat recurrent instability; A UK case series. J Orthop. 2019;16(3):2203.

121. Viste A, Desmarchelier R, Fessy MH. Dual mobility cups in revision total hip arthroplasty. International Orthopaedics. 2017:41(3):535-42.

122. Puch JM, Derhi G, Descamps L, Verdier R, Caton JH. Dual-mobility cup in total hip arthroplasty in patients less than fifty five years and over ten years of follow-up : A prospective and comparative series. International Orthopaedics. 2017:41(3):475-80.

123. Martz P, Maczynski A, Elsair S, Labattut L, Viard B, Baulot E. Total hip arthroplasty with dual mobility cup in osteonecrosis of the femoral head in young patients: over ten years of follow-up. International Orthopaedics. 2017:41(3):605-10

124. Hernigou P, Auregan JC, Potage D, Roubineau F, Flouzat Lachaniette CH, Dubory A. Dual-mobility implants prevent hip dislocation following hip revision in obese patients. International Orthopaedics. 2017;41(3):469-73.

125. Hamadouche M, Ropars M, Rodaix C, Musset T, Gaucher F, Biau D, et al. Five to thirteen year results of a cemented dual mobility socket to treat recurrent dislocation. International Orthopaedics. 2017;41(3):513-9.

126. Gonzalez Al, Bartolone P, Lubbeke A, Dupuis Lozeron E, Peter R, Hoffmeyer $P$, et al. Comparison of dual-mobility cup and unipolar cup for prevention of dislocation after revision total hip arthroplasty. Acta Orthop. 2017;88(1): 18-23.

127. Nich C, Vandenbussche E, Augereau B, Sadaka J. Do dual-mobility cups reduce the risk of dislocation in total hip arthroplasty for fractured neck of femur in patients aged older than 75 years? J Arthroplasty. 2016;31(6):125660.

128. Jauregui JJ, Pierce TP, Elmallah RK, Cherian JJ, Delanois RE, Mont MA. Dual mobility cups: an effective prosthesis in revision total hip arthroplasties for preventing dislocations. Hip Int. 2016;26(1):57-61.

129. Homma Y, Baba T, Kobayashi H, Desroches A, Ochi H, Ozaki Y, et al. Benefit and risk in short term after total hip arthroplasty by direct anterior approach combined with dual mobility cup. European Journal of Orthopaedic Surgery \& Traumatology : Orthopedie Traumatologie. 2016;26(6):619-24.

130. Haughom BD, Plummer DR, Moric M, Della Valle CJ. Is there a benefit to head size greater than $36 \mathrm{~mm}$ in total hip arthroplasty? J Arthroplasty. 2016; 31(1):152-5

131. Chughtai M, Mistry JB, Diedrich AM, Jauregui JJ, Elmallah RK, Bonutti PM, et al. Low frequency of early complications with dual-mobility acetabular cups in cementless primary THA. Clinical Orthopaedics and Related Research. 2016;474(10):2181-7.

132. Wegrzyn J, Tebaa E, Jacquel A, Carret JP, Bejui-Hugues J, Pibarot V. Can dual mobility cups prevent dislocation in all situations after revision total hip arthroplasty? J Arthroplasty. 2015;30(4):631-40.

133. Vigdorchik JM, D'Apuzzo MR, Markel DC, Malkani AL, Raterman S, Sharpe KP, et al. Lack of early dislocation following total hip arthroplasty with a new dual mobility acetabular design. Hip Int. 2015;25(1):34-8.

134. Vermersch T, Viste A, Desmarchelier R, Fessy MH. Prospective longitudinal study of one hundred patients with total hip arthroplasty using a secondgeneration cementless dual-mobility cup. International Orthopaedics. 2015; 39(11):2097-101.

135. van Heumen M, Heesterbeek PJ, Swierstra BA, Van Hellemondt GG, Goosen $J \mathrm{H}$. Dual mobility acetabular component in revision total hip arthroplasty for 
persistent dislocation: no dislocations in 50 hips after 1-5 years. Journal of orthopaedics and Traumatology: Official Journal of the Italian Society of Orthopaedics and Traumatology. 2015;16(1):15-20.

136. Simian E, Chatellard R, Druon J, Berhouet J, Rosset P. Dual mobility cup in revision total hip arthroplasty: dislocation rate and survival after 5 years. Orthopaedics \& Traumatology, Surgery \& Research : OTSR. 2015;101(5):57781.

137. Mohammed R, Hayward K, Mulay S, Bindi F, Wallace M. Outcomes of dualmobility acetabular cup for instability in primary and revision total hip arthroplasty. Journal of Orthopaedics and Traumatology : Official Journal of the Italian Society of Orthopaedics and Traumatology. 2015;16(1):9-13.

138. Epinette JA. Clinical outcomes, survivorship and adverse events with mobile-bearings versus fixed-bearings in hip arthroplasty-a prospective comparative cohort study of 143 ADM versus 130 trident cups at 2 to 6 year follow-up. J Arthroplasty. 2015;30(2):241-8.

139. Bel JC, Carret JP. Total hip arthroplasty with minimal invasive surgery in elderly patients with neck of femur fractures: our institutional experience. Injury. 2015;46(Suppl 1):S13-7.

140. Wegrzyn J, Pibarot V, Jacquel A, Carret JP, Bejui-Hugues J, Guyen O. Acetabular reconstruction using a Kerboull cross-plate, structural allograft and cemented dual-mobility cup in revision THA at a minimum 5-year follow-up. J Arthroplasty. 2014;29(2):432-7.

141. Prudhon JL, Steffann F, Ferreira A, Verdier R, Aslanian T, Caton J. Cementless dual-mobility cup in total hip arthroplasty revision. International Orthopaedics. 2014;38(12):2463-8.

142. Jakobsen T, Kappel A, Hansen F, Krarup N. The dislocating hip replacement revision with a dual mobility cup in 56 consecutive patients. Open Orthop J. 2014;8:268-71.

143. Epinette JA, Beracassat R, Tracol P, Pagazani G, Vandenbussche E. Are modern dual mobility cups a valuable option in reducing instability after primary hip arthroplasty, even in younger patients? J Arthroplasty. 2014; 29(6):1323-8.

144. Caton JH, Prudhon JL, Ferreira A, Aslanian T, Verdier R. A comparative and retrospective study of three hundred and twenty primary Charnley type hip replacements with a minimum follow up of ten years to assess whether a dual mobility cup has a decreased dislocation risk. International Orthopaedics. 2014;38(6):1125-9.

145. Bensen AS, Jakobsen T, Krarup N. Dual mobility cup reduces dislocation and re-operation when used to treat displaced femoral neck fractures. International Orthopaedics. 2014;38(6):1241-5.

146. Tarasevicius S, Robertsson O, Dobozinskas P, Wingstrand H. A comparison of outcomes and dislocation rates using dual articulation cups and THA for intracapsular femoral neck fractures. Hip Int. 2013;23(1):22-6.

147. Saragaglia D, Ruatti S, Refaie R. Relevance of a press-fit dual mobility cup to deal with recurrent dislocation of conventional total hip arthroplasty: a 29case series. European Journal of Orthopaedic Surgery \& Traumatology : Orthopedie Traumatologie. 2013;23(4):431-6.

148. Sanders RJ, Swierstra BA, Goosen JH. The use of a dual-mobility concept in total hip arthroplasty patients with spastic disorders: no dislocations in a series of ten cases at midterm follow-up. Arch Orthop Trauma Surg. 2013; 133(7):1011-6.

149. Prudhon JL, Ferreira A, Verdier R. Dual mobility cup: dislocation rate and survivorship at ten years of follow-up. International Orthopaedics. 2013; 37(12):2345-50.

150. Hamadouche M, Arnould $H$, Bouxin B. Is a cementless dual mobility socket in primary THA a reasonable option? Clinical Orthopaedics and Related Research. 2012;470(11):3048-53.

151. Hailer NP, Weiss RJ, Stark A, Karrholm J. Dual-mobility cups for revision due to instability are associated with a low rate of re-revisions due to dislocation: 228 patients from the Swedish Hip Arthroplasty Register. Acta Orthop. 2012;83(6):566-71.

152. Civinini R, Carulli C, Matassi F, Nistri L, Innocenti M. A dual-mobility cup reduces risk of dislocation in isolated acetabular revisions. Clinical Orthopaedics and Related Research. 2012;470(12):3542-8.

153. Adam P, Philippe R, Ehlinger M, Roche O, Bonnomet F, Mole D, et al. Dual mobility cups hip arthroplasty as a treatment for displaced fracture of the femoral neck in the elderly. A prospective, systematic, multicenter study with specific focus on postoperative dislocation. Orthopaedics \& Traumatology, Surgery \& Research : OTSR. 2012;98(3):296-300.

154. Schneider L, Philippot R, Boyer B, Farizon F. Revision total hip arthroplasty using a reconstruction cage device and a cemented dual mobility cup.
Orthopaedics \& Traumatology, Surgery \& Research : OTSR. 2011;97(8):80713.

155. Bouchet R, Mercier N, Saragaglia D. Posterior approach and dislocation rate: a 213 total hip replacements case-control study comparing the dual mobility cup with a conventional 28-mm metal head/polyethylene prosthesis. Orthopaedics \& Traumatology, Surgery \& Research : OTSR. 2011; 97(1):2-7.

156. Tarasevicius S, Busevicius M, Robertsson $O$, Wingstrand $H$. Dual mobility cup reduces dislocation rate after arthroplasty for femoral neck fracture. BMC Musculoskelet Disord. 2010;11:175.

157. Hamadouche M, Biau DJ, Huten D, Musset T, Gaucher F. The use of a cemented dual mobility socket to treat recurrent dislocation. Clinical Orthopaedics and Related Research. 2010;468(12):3248-54

158. Guyen O, Pibarot V, Vaz G, Chevillotte C, Bejui-Hugues J. Use of a dual mobility socket to manage total hip arthroplasty instability. Clinical Orthopaedics and Related Research. 2009;467(2):465-72.

159. Langlais FL, Ropars M, Gaucher F, Musset T, Chaix O. Dual mobility cemented cups have low dislocation rates in THA revisions. Clinical Orthopaedics and Related Research. 2008;466(2):389-95.

160. Bauchu P, Bonnard O, Cypres A, Fiquet A, Girardin P, Noyer D. The dualmobility POLARCUP: first results from a multicenter study. Orthopedics. 2008;31(12 Suppl 2).

161. Pattyn C, Audenaert E. Early complications after revision total hip arthroplasty with cemented dual-mobility socket and reinforcement ring. Acta Orthop Belg. 2012;78(3):357-61.

162. Vasukutty NL, Middleton RG, Matthews EC, Young PS, Uzoigwe CE, Minhas $\mathrm{TH}$. The double-mobility acetabular component in revision total hip replacement: the United Kingdom experience. The Journal of Bone and Joint Surgery British. 2012;94(5):603-8.

163. Snir N, Park BK, Garofolo G, Marwin SE. Revision of failed hip resurfacing and large metal-on-metal total hip arthroplasty using dual-mobility components. Orthopedics. 2015;38(6):369-74.

164. Gaudin G, Ferreira A, Gaillard R, Prudhon JL, Caton JH, Lustig S. Equivalent wear performance of dual mobility bearing compared with standard bearing in total hip arthroplasty: in vitro study. International Orthopaedics. 2017:41(3):521-7.

165. Geringer J, Boyer B, Farizon F. Understanding the dual mobility concept for total hip arthroplasty. Investigations on a multiscale analysis-highlighting the role of arthrofibrosis. Wear. 2011;271(9):2379-85.

166. Imbert L, Geringer J, Boyer B, Farizon F. Wear analysis of hip explants, dual mobility concept: Comparison of quantitative and qualitative analyses. Proceedings of the Institution of Mechanical Engineers, Part J: Journal of Engineering Tribology. 2012;226(10):838-53.

167. Boyer B, Neri T, Geringer J, Di lorio A, Philippot R, Farizon F. Long-term wear of dual mobility total hip replacement cups: explant study. International Orthopaedics. 2018:42(1):41-7.

168. Boyer B, Neri T, Geringer J, Di lorio A, Philippot R, Farizon F. Understanding wear in dual mobility total hip replacement: first generation explant wear patterns. International Orthopaedics. 2017;41(3):529-33.

169. Boyer B, Neri T, Di lorio A, Geringer J, Philippot R, Farizon F. The linear penetration rate is not relevant for evaluating wear of dual mobility cups: an explant study. International Orthopaedics. 2017;41(3):599-603.

170. Loving L, Herrera L, Banerjee S, Heffernan C, Nevelos J, Markel DC, et al. Dual mobility bearings withstand loading from steeper cup-inclinations without substantial wear. J Orthop Res. 2015;33(3):398-404.

171. Callary SA, Solomon LB, Holubowycz OT, Campbell DG, Munn Z, Howie DW. Wear of highly crosslinked polyethylene acetabular components. Acta Orthop. 2015;86(2):159-68.

172. Deckard ER, Azzam KA, Meneghini RM. Contemporary Dual Mobility Head Penetration at Five Years: Concern for the Additional Convex Bearing Surface? J Arthroplasty. 2018;33(7S):S280-S4

173. Australian Orthopaedic Association National Joint Replacement Registry. Annual report 2019. 2019; https://aoanjrr.sahmri.com/annual-reports-2019. Accessed 13 Sept 2020.

174. National Joint Registry for England W, Northern Ireland, and the Isle of Man. National Joint Registry for England, Wales, Northern Ireland, and the Isle of Man 16th annual report, 2019. 2019;https://reports.njrcentre.org.uk/downloa ds. Accessed 13 Sept 2020.

175. Tarity TD, Koch CN, Burket JC, Wright TM, Westrich GH. Fretting and corrosion at the backside of modular cobalt chromium acetabular inserts: a retrieval analysis. J Arthroplasty. 2017;32(3):1033-9. 
176. Hothi HS, Ilo K, Whittaker RK, Eskelinen A, Skinner JA, Hart AJ. Corrosion of metal modular cup liners. J Arthroplasty. 2015;30(9):1652-6.

177. Kolz JM, Wyles CC, Van Citters DW, Chapman RM, Trousdale RT, Berry DJ. In vivo corrosion of modular dual-mobility implants: a retrieval study. J Arthroplasty. 2020.

178. Wiley KF, Ding K, Stoner JA, Teaque DC, Yousuf KM. Incidence of pseudotumor and acute lymphocytic vasculitis associated lesion (ALVAL) reactions in metal-on-metal hip articulations: a meta-analysis. J Arthroplasty. 2013;28(7):1238-45.

179. Matsen Ko L, Pollag KE, Yoo JY, Sharkey PF. Serum metal ion levels following total hip arthroplasty with modular dual mobility components. J Arthroplasty. 2016;31(1):186-9.

180. D'Apuzzo MR, Koch CN, Esposito Cl, Elpers ME, Wright TM, Westrich GH. Assessment of damage on a dual mobility acetabular system. J Arthroplasty. 2016;31(8):1828-35.

181. Neri T, Boyer B, Geringer J, Di lorio A, Caton JH, Philippot R, et al. Intraprosthetic dislocation of dual mobility total hip arthroplasty: still occurring? International Orthopaedics. 2019;43(5):1097-105.

182. De Martino I, D'Apolito R, Waddell BS, McLawhorn AS, Sculco PK, Sculco TP. Early intraprosthetic dislocation in dual-mobility implants: a systematic review. Arthroplast Today. 2017;3(3):197-202.

183. Evans JT, Evans JP, Walker RW, Blom AW, Whitehouse MR, Sayers A. How long does a hip replacement last? A systematic review and meta-analysis of case series and national registry reports with more than 15 years of followup. Lancet. 2019;393(10172):647-54.

184. Van Eecke E, Vanbiervliet J, Dauwe J, Mulier M. Comparison of constrained acetabular components and dual mobility cups in revision total hip arthroplasty: a literature review. Hip Pelvis. 2020;32(2):59-69.

185. Wright EA, Katz JN, Baron JA, Wright RJ, Malchau H, Mahomed N, et al. Risk factors for revision of primary total hip replacement: results from a national case-control study. Arthritis Care Res (Hoboken). 2012;64(12):1879-85.

186. Prokopetz JJ, Losina E, Bliss RL, Wright J, Baron JA, Katz JN. Risk factors for revision of primary total hip arthroplasty: a systematic review. BMC Musculoskelet Disord. 2012;13:251.

187. Inacio MC, Ake CF, Paxton EW, Khatod M, Wang C, Gross TP, et al. Sex and risk of hip implant failure: assessing total hip arthroplasty outcomes in the United States. JAMA Intern Med. 2013:173(6):435-41.

188. Karachalios T, Komnos G, Koutalos A. Total hip arthroplasty: Survival and modes of failure. EFORT Open Rev. 2018;3(5):232-9.

\section{Publisher's Note}

Springer Nature remains neutral with regard to jurisdictional claims in published maps and institutional affiliations.

Ready to submit your research? Choose BMC and benefit from:

- fast, convenient online submission

- thorough peer review by experienced researchers in your field

- rapid publication on acceptance

- support for research data, including large and complex data types

- gold Open Access which fosters wider collaboration and increased citations

- maximum visibility for your research: over $100 \mathrm{M}$ website views per year

At BMC, research is always in progress.

Learn more biomedcentral.com/submissions 